2015

\title{
Redefining Professionalism
}

Rebecca Roiphe

New York Law School

Follow this and additional works at: http://digitalcommons.nyls.edu/fac_articles_chapters

Part of the Legal Education Commons, Legal Ethics and Professional Responsibility Commons, and the Legal Profession Commons

\section{Recommended Citation}

26 U. Fla. J.L. \& Pub. Pol'y 193 (2015)

This Article is brought to you for free and open access by the Faculty Scholarship at DigitalCommons@NYLS. It has been accepted for inclusion in Articles \& Chapters by an authorized administrator of DigitalCommons@NYLS. 


\section{REDEFINING PROFESSIONALISM}

(C) 2015 Rebecca Roiphe

INTRODUCTION

I. INDEPENDENCE: DEFINITION AND ORIGIN................................200

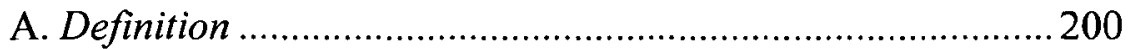

B. History of Professional Independence .................................203

II. PROFESSIONAL INDEPENDENCE IN CONTEXT ............................210

A. Defending the Robber Barons ............................................211

B. The Legal Services Bureau....................................................216

C. The McCarthy Era Loyalty Oaths ........................................221

III. Salvaging THE Notion of Professional INDEPENDENCE......229

IV. IMPLICATIONS FOR A MODERN CONCEPT OF

PROFESSIONAL INDEPENDENCE.................................................223

A. The Correspondence Between Bowles and Field...................231

B. A Federally Funded Legal Service Corporation................... 237

C. The McCarthy Era.............................................................. 238

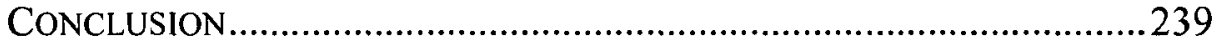

\section{INTRODUCTION}

The American legal profession is experiencing a revolution in the way legal services are provided and how consumers access those services. ${ }^{1}$

* Professor of Law, New York Law School. Ph.D. University of Chicago. J.D. Harvard Law School. I am grateful to Elizabeth Chambliss, Doni Gewirtzman, Bruce Green, Molly Land, Ed Purcell, and Bradley Wendel for their comments on this Article. The Article benefited from the insights of the participants in the Hofstra Law School Roundtable on Ethics organized by Professor Susan Fortney. I would also like to thank N.Y. Law School for its research support.

1. See, e.g., William D. Henderson, Three Generations of U.S. Lowyers: Generalists, Specialists, Project Managers, 70 MD. L. Rev. 373 (2011); Richard SusSKInd, TOMORRow's LAWYERS: AN INTRODUCTION TO YOUR FUTURE (2014). For a good effort to organize the new forms of legal services, see Jordan Furlong, An Incomplete Inventory of New Law, LAW 21 BLoG (May 13, 2014), http://www.law21.ca/2014/05/incomplete-inventory-newlaw/. Among other changes in the profession inspired by the increasingly global and technology driven marketplace is a push for deregulation. Benjamin H. Barton, Economists of Deregulation of the American Legal Profession: Praise and Critique, 2012 MiCH. ST. L. REV. 493 (2012). While deregulation might be a welcome innovation, it also implies a faith in the marketplace. Id. Before we surrender 
Without fully understanding this shift, we are struggling to grasp what some have called a crisis in legal education. ${ }^{2}$ As we meet these challenges, it is important to embrace innovation and change while preserving what has been valuable and useful about the legal profession in the past. By exploring the history of professional independence, this Article seeks to elaborate what is essential and worth maintaining as the profession adapts to the changing market for legal services. The answer has important implications for the future of legal education as well as the regulation of the legal profession.

As a part of the assault on professionalism, critics argue that the idea of professional independence is empty rhetoric, designed to mask protectionist and self-interested conduct as necessary measures to ensure lawyers' self-sacrificing dedication to the public good. ${ }^{3}$ This particular criticism is part of a larger prediction and celebration of the end of the American legal profession. ${ }^{4}$ Without advocating a mindless return to the way things once were, this Article serves as a reminder that the idea of

completely to the forces of the market, this Article serves a reminder of some of the advantages of a more guild like approach to the professions. Once we recognize the advantages, the next step would be to see if we can integrate them into a more modern and dynamic approach to the delivery of legal services.

2. Stephen Harper, The lawyer Bubble: A Profession in Crisis 54 (2013); Paul Horwitz, What AILS THE LAW SCHOOLS 955 (1913); WALTER Olson, SCHOOLS FOR MiSRULE: Legal ACAdemia AND an Overlawyered America (2012); Paul Campos, The Crisis of the American Law School, 46 U. MiCH. J.L. Reform 177, 177 (2012); Bryant G. Garth, Crises, Crisis Rhetoric, and Competition in Legal Education: A Sociological Perspective on the (Latest) Crisis of the Legal Profession and Legal Education, 24 STAN. L \& POL'Y REV. 503 (2013); Paul Horwitz, What Ails the Law Schools, 111 Mich. L. REv. Pol. 955, 956 (2013); see Richard A. Matasar, The Rise and Fall of American Legal Education, 49 N.Y.L. SCH. L. REV. 465, 496 (2004); William D. Henderson \& Rachel M. Zahorsky, The Law School Bubble: How Long Will it Last if Law Grads Can't Pay Bills?, A.B.A. J. (Jan. 1, 2012), available at hitp://www.abajournal.com/ magazine/article/the_law_school_bubble_how_long_will_it_last_if_law_grads_cant_pay_bills/.

3. See, e.g., THOMAS MORGAN, THE VANISHING AMERICAN LAWYER (2010).

4. Id.; RICHARD SUSSKIND, THE END OF LAWYERS?: RETHINKING THE NATURE OF LEGAL Services (2008); Richard K. Greenstein, Against Professionalism, 22 Geo. J. Legal ETHICs 327 (2009). For a classic discussion of the decline in professionalism, see RiCHARD L. ABEL, AMERICAN LAWYERS 226-49 (1989). Recently, Daniel Markovits has concluded that the professional life ends in tragedy because life of a lawyer is not worth living given the growingly diffuse and diverse nature of legal practice. Daniel Markovits, A MODERN Legal ETHICS: ADVERSARY ADVOCACY IN THE MODERN AGE 212-47 (2012). The prediction of the end of the legal profession as we know it is not new, but the challenges facing every generation of lawyers is different. See Russell G. Pearce, The Professionalism Paradigm Shift: Why Discarding Professional Ideology Will Improve the Conduct and Reputation of the Bar, 70 N.Y.U. L. REv. 1229 (1995). Mary A. Glendon, A Nation Under Lawyers: How the Crisis in the Legal Profession IS TRANSFORMING AMERICAN SOCIETy (1994); ANTHONY T. KRONMAN, THE LOST

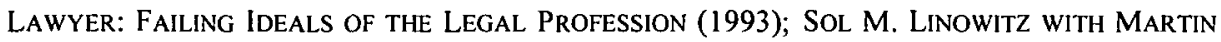
Mayer, The Betrayed Profession: Lawyering at the End of the Twentieth Century (1994). 
professional independence has been beneficial. At the very least, it has provided a useful way for lawyers to talk about, develop, and redefine their role in a constantly evolving democratic system. ${ }^{5}$ As such, it is worth thinking about how we can preserve the ideal of independence without ignoring the reality of a changed legal landscape.

The criticism of the concept of independence is not new. The historiography of professional independence echoes the current hostility toward the legal profession. ${ }^{6}$ Professional independence, historians like Jerold Auerbach argue, is part of a rhetoric that has served to support the interests of a particular economic and social class. It is part of a language of professionalism used to exclude outsiders, artificially inflate professional status, and sustain market monopolies. ${ }^{7}$ Oddly, this Marxist/Weberian critique of professionalism has survived, almost unchanged, for decades. ${ }^{8}$ Without refuting the valuable insight of Auerbach and others who have developed this critique, this Article articulates an alternate narrative to explain the persistence of professionalism, by focusing on professional independence. ${ }^{9}$

To that end, I have unearthed three controversies in which lawyers debated perceived threats to both the profession in particular and democratic ideals in general in terms of professional independence. By doing so, I resurrect a more beneficial and positive use of the term, which can be sustained as the profession itself changes. Together, these three episodes demonstrate that the notion of professional independencewhile always hazy and vague-is not merely a tool in a self-interested pursuit of market interests. It is also part of a language of professional identity, an evolving understanding of what it means to be a lawyer in America. Lawyers have used the idea of independence to elaborate a common identity and debate what that shared identity means at any given time. While they might never agree and, if they do, history might prove any of their assumptions wrong or misguided, I argue that the process itself is worth preserving, as it allows for the evolution of the profession's role. This in turn pushes an individual lawyer to connect her work to a

5. For an interesting discussion of the critical role of professionalism in preserving the rule of law and democratic values in China, see Sida Liu et al., The Trial of Li Zhuang: Chinese Lawyers' Collective Action Against Populism, 1 AsIAN J.L. \& SOC'Y 79 (2014).

6. Jerold S. AuerbaCH, LAWYers and SOClal Change IN AMERICA 45-46 (1976).

7. Id. A few historians have presented alternative narratives of the profession and professionalism. See e.g., Terrence Halliday, The Idiom of Legalism in Bar Politics: Lawyers, McCarthyism, and the Civil Rights Era, 1982 AM. B. FouND. RES. J. 911 (1982); SAMUEL HABER, THE QUEST FOR AUTHORITY AND HONOR IN THE AMERICAN PROFESSIONS, 1750-1900 (1991).

8. For a summary of the Marxist-Weberian critique of the professions, see ABEL, supra note 4 , at $14-40$.

9. For my first article developing this argument, see Rebecca Roiphe, A History of Professionalism: Julius Henry Cahen and the Professions as a Route to Citizenship, 40 FORDHAM URB. L.J. 33 (2013). 
larger purpose, even when the nature of that larger purpose remains elusive.

Drawing on my conclusion that independence is an aspect of professional identity rather than a condition that results from the isolation of lawyers from businessmen and others, I argue that the concept has been marshaled to support unwarranted goals. The real threat to independence does not come from innovative markets, sources of funding, or new law firm structures, as many assume. ${ }^{10}$ The danger, instead, arises from proposals to segment the profession in ways that might erode a common identity and divorce lawyers from a shared history. ${ }^{11}$ Reconceiving professional independence in this way renders it flexible enough to survive the massive changes in the profession while continuing to shape the nature of the profession and its aspirations. ${ }^{12}$

Critics tend to focus on the pernicious uses of professional independence, but, like most concepts, it is an elastic ideal which has been used for disparate purposes. ${ }^{13}$ It has not served one constituency, ideology, or program, but it has consistently provided a language for debating the nature of the lawyer's role in a democracy. While the idea of professional independence has been used for both trivial and selfserving purposes, it has also served as a reminder of the value of lawyers in a democracy. It has provided a language, albeit an imprecise one, to discuss and debate the evolving role the profession must play as the landscape changes. ${ }^{14}$

10. Michele M. Destefano, Nonlawyers Influencing Lawyers: Too Many Cooks in the Kitchen or Stone Soup?, 80 FordHAM L. REV. 2791, 2793 (2012) (arguing that the bar has been misguided in its restriction of multidisciplinary practice); Edward S. Adams \& John H. Matheson, Law Firms on the Big Board?: A Proposal for Nonlawyer Investment in Law Firms, 86 CAL. L. REV. 1, 30-37 (1998) (arguing against the bar's position on nonlawyer investment in law firms); Larry E. Ribstein, The Death of Big Law, 2010 WIS. L. REV. 749, 797-800 (2010) (arguing against ownership and investment restrictions).

11. The most prominent proponent of this kind of segmentation is Brian Tamanaha. See BRIAN Z. TAManaha, Failing LaW SCHOOLS 167-86 (2012).

12. Sociologist Herbert Kritzer argues that the professions are going through a revolutionary transition. Herbert M. Kritzer, The Professions are Dead, Long Live the Professions: Legal Practice in a Postprofessional World, 33 LAW \& Soc'Y REV. 713 (1999). Kritzer argues that the professions will take a radical new form rather than simply becoming extinct. Id. As such, it is critical to preserve what has been useful about the profession in the past by recasting professionalism in a way that can survive the many changes in the profession. By reconceiving professional independence as an aspect of professional identity, the concept will be able to survive the changes that have already revolutionized the delivery of legal services in America.

13. AUERBACH, supra note 6 , at $40-73$.

14. Aziz Rana has argued that work provides an important site for individuals to participate in and contribute to a democratic community. Aziz Rana, Statesman or Scribe?: Legal Independence and the Problem of Democratic Citizenship, 77 FordHAM L. REV. 1665, 1694-99 (2009). It is hard for work, alone, to serve this function. Work combined with a sense of shared history and identity, however, can, as sociologist Émile Durkheim suggested, provide a way for 
Given this essential function, it is critical to resist recent calls to dissolve the notion of a unitary legal profession entirely. The ideal of a lawyer's independence (which is only coherent if we preserve the integrity of a profession united at least in some way) provides a language with which to discuss the lawyer's role in society. While it has been abused and corralled into service of self-interested pursuits at times, it has also brought lawyers together in an evolving and useful dialog about what it means to be a lawyer and the role the profession ought to play in a democracy. The conversation itself has proved helpful in pushing ourselves to define and redefine, criticize and justify, in search of a common professional identity.

By unearthing different historical understandings of independence and how the term has been used at different times, what agenda it has served, this Article also suggests that we ought to use the term in a more precise manner. The ABA has made grand claims about independence. For instance, the 1992 MacCrate Report insisted that the practice of law is "a single public profession of shared learning, skills and professional values" and that self-regulation is essential to ensure "independence from government domination, permitting the profession to be an important force in preserving government under law . ..."15 This sentiment has been invoked so many times to support unnecessary and self-interested proposals that it is in danger of losing any potential to motivate a useful debate over the future of the profession. The distinction between a profession and a business does not capture the full meaning of independence. It is confusing and leaves the concept open to obvious criticism. ${ }^{16}$ Identifying what particular aspect of independence is at issue, and what values are really in jeopardy, will help move the conversation away from the platitudes that are bandied about in the wood paneled bar association meeting rooms to a more concrete discussion of practical import.

Building on decades of literature about the legal profession, many critics believe that professionalism is at best an empty, and, at worst, a

individuals to interact productively in a complex modern society. If we relinquish the notion of a profession entirely, we give up that potential. ÉMILE DURKHEIM, PROFESSIONAL ETHICS AND CIVIC Morals 10-14 (Cornelia Brookfield trans., Free Press 1958).

15. Section of Legal Education \& Admissions to the Bar, american bar association, legal Education and Professional Development-An Educational CONTINUUm, Report of the Task Force on LaW Schools and tHe Profession: Narrowing THE GAP 119-20 (1992) [hereinafter MACCRATE REPORT].

16. Pearce, supra note 4 , at $1246-63$. The functional sociologists acknowledged that the distinction between the professions as public service and business as self-interested is oversimplified and inaccurate. See Talcott Parsons, The Professions and Social Structure, in Essays in SOCIOlogical Theory 34-35 (Talcott Parsons ed., 1954); Talcott Parsons, A Sociologist Looks at the Legal Profession, in EsSAYS IN SOCIOLOGICAL THEORY 370 (rev. ed. 1954). 
destructive term. ${ }^{17}$ Some are ready to dispense with the idea entirely along with a notion that there is anything unique about those who practice law. ${ }^{18}$ Others feel sure that the profession itself is about to dissolve as we splinter into specialties that have little to do with one another. ${ }^{19}$ Sociologists have explained that increased specialization and the spread of information technology have created conditions that put the professions in jeopardy. ${ }^{20}$ Legal scholars have echoed this prediction. ${ }^{21}$ If there is any potential to preserve something useful about professionalism it will derive from the skills that all lawyers share, despite the increased specialization. $^{22}$ Similarly, given that technology has democratized access to knowledge and information, it follows that if professionals contribute anything unique, then it must be in their technique or approach, which cannot be disseminated as easily as information and knowledge.

In the same spirit as those who would have us abolish the profession, critics have called for radical restructuring of legal education. ${ }^{23}$ Critics have suggested two-year law schools, segmentation, specialization, and other reforms. ${ }^{24}$ This Article uses the new definition of independence and professionalism to argue that if we move to a different model of legal education, we should retain some common ground-we should not forget to engage in the difficult conversation about what positive attributes ought to draw the profession together. If professional independence is a product of group identity then the process of socialization through education is key in instilling the sense of a common mission. ${ }^{25}$

There are unique risks in the proposed segmentation of law schools

17. Id.; MORGAN, supra note 3, at 19-40; SUSSKIND, supra note 4 .

18. See Pearce, supra note 4, at 1263-76; MORGAN, supra note 3, at 19-40; SUSSKIND, supra note 4.

19. Sociologists have explained that the professions have become increasingly segmented and specialized over the course of the last century. See Michael Ariens, Know the Law: A History of Legal Specialization, 45 S.C. L. REV. 1003 (1994). Specialization, other theorists argue, threatens the idea of a unified profession. Simon H. Rifkind, Shift to Specialization Biggest Change in Law, N.Y. L.J., May 23, 1988, at S36. The MacCrate Report comes to a similar conclusion. MACCRATE REPORT, supra note 15. TASK FORCE ON LAW SCHOOLS AND THE Profession: NARRowing THE GAP, AMERICAN BAR ASs'N, LEGal EdUCATION AND Professional DEVElopment-An EduCATIONAL CONTINUUM 42 (1992).

20. Kritzer, supra note 12 , at 726-28.

21. MORGAN, supra note 3, at 6-9; SUSSKIND, supra note 4.

22. One such skill unique to lawyers is the ability to relate with clients. See CAROLL SERON, THE Business of PRACTICING LAW: THE WORK Lives of SOlo AND SMALl-FiRM ATTORNEYS 106 (1996) (describing the importance of the personal relationship with the lawyer to clients).

23. TAMANAHA, supra note 11, at 1-8; Campos, supra note 2, at 215-16.

24. Campos, supra note 2, at 215-22.

25. A number of scholars have written about law school and the process of socialization. See, e.g., John O. Calmore, "Chasing the Wind": Pursuing Social Justice, Overcoming Legal MisEducation, and Engaging in Professional Re-Socialization, 37 LOY. L.A. L. REV. 1167 (2004); Robert Granfield, Constructing Professional Boundaries in Law School: Reactions of Students and Implications for Teachers, 4 S. CAL. REV. L. \& WOMEN's STUD. 53, 64-70 (1994). 
into top tier, which would train our country's leaders in industry and government, and bottom tier schools, which prepare tradesmen for the "simple" work of representing clients. ${ }^{26}$ Aside from the misguided assumption that only large firm lawyers and national policy makers need access to a complex theoretical understanding of the law, there is also the risk that lawyers lose a common ground, which is valuable. While innovating, law schools and professionals should remember to ask: What is common to the practice of law? What unites all lawyers in common professional identity? And, what has been useful and productive in the profession in the past? This Article begins to answer these questions by resuscitating a history of professional independence, which has been useful in the past.

To make this argument, Part I of this Article will provide a basic definition of professional independence with the understanding that the term is complex and vague and has shifted in meaning over time. This first section will also explore the origin and meaning of independence around the time of founding. Part II of this Article will provide three examples of how American lawyers have employed the term throughout the twentieth century. Finally, I will use these examples to explore the implications of these anecdotes. Part III will draw two conclusions. It will emphasize how these three examples, taken together, provide a historical counterargument to the current eagerness to dispense with professionalism and the notion of professional independence along with it. It will also draw on these three episodes to conclude that professional independence ought to be seen as an aspect of professional identity, not a product of structural relationships. Therefore, professional independence cannot support the ABA's opposition to multidisciplinary practice, outside funding of law practice, and non-lawyer investment in lawsuits.

The same forces that have led to innovation in legal practice and education-globalization and advances in information technologymake this project more critical. As we move to a global legal community, as we work with other countries, with other legal systems, it is important to locate and retain what it is that is valuable in the history and traditions of the American legal profession. The market pressure to compete and conform, along with the exciting project of innovating, can lead us to race into the future without consulting the past. This project serves as a break to that momentum. It concludes that a profession, which aspires to be independent of its clients, popular opinion, and the government, in all its vagueness, is a critical component of a democratic state and one that we should not relinquish without a fight.

26. The most prominent proponent of this model is Brian Tamanaha. See TAMANAHA, supra note 11 , at 167-86. 
This conclusion helps shape heated contemporary debates about the profession. First, it contributes to the literature on the professional role by arguing that ethics is not grounded in morality or politics, but rather in the nature of the work lawyers do in balancing contradictory interests. Second, it helps clarify and shape pressing conversations about the regulation of the profession and the future of legal education. And finally, it articulates a conception of independence and professionalism that is capable of surviving the recent, monumental changes in the profession.

\section{INDEPENDENCE: DEFINITION AND ORIGIN}

This Part offers a brief definition of independence and then sketches its origin and development throughout American history. Doing so establishes a basic meaning for the term but also highlights how plastic the concept has been.

\section{A. Definition}

Louis Brandeis defined professional independence in a famous speech entitled, "Opportunity in the Law." ${ }^{27} \mathrm{He}$ explained that lawyers ought to hold a "position of independence, between the wealthy and the people, prepared to curb the excess of either." 28 This is, of course, just one articulation of many. Professor Robert Gordon has masterfully deconstructed and outlined the various understandings of independence. ${ }^{29} \mathrm{He}$ suggests that independence can denote corporate self-regulation or control over the conditions of the lawyers' work. ${ }^{30}$ Gordon, however, focuses more closely on a third use of the term-the profession's status as a "separate estate." 31 By this, he means two things. First, law yers are ideaily independent from the State. ${ }^{32}$ As such, they can act to ensure that the government abides by its own laws. ${ }^{33}$ Second, lawyers are independent from clienteles, which allows them to protect the public and guard the rule of law from the selfish grasp of powerful factions. ${ }^{34}$

Like Gordon, I am mostly concerned with the idea of independence as a separate estate, guarding against the power of both the government and

27. Louis D. Brandeis, The Opportunity in the Law, Address Before the Harvard Ethical Society (May 4, 1905), in BUSINESS: A PROFESSION 329 (1914).

28. Id. at 337.

29. Robert W. Gordon, The Independence of Lawyers, 68 B.U. L. REV. 1, 1-30 (1988).

30. Id. at $6-8$.

31. Id. at $9-10$.

32. Id. at $10-11$.

33. Id.

34. Id. at 11-29. 
substantial private interests. In this concept of professional independence, lawyers hover somewhere between clients and the government or the law. They fight to effectuate their clients' interests but they do so by negotiating, counseling, and arguing about the meaning of the country's shared norms, which are (albeit clumsily) articulated through positive law. ${ }^{35}$ That very purpose ingrained in our sometimes unrealistic aspirations for lawyers is a part of an identity that derives from the work all lawyers do in trying to realize private interest through the confines of the law. ${ }^{36}$

Recently, lawyers and regulators have invoked professional independence to debate practical reforms, like whether or not to allow outside investors in law firms and whether lawyers ought to be able to practice alongside other professionals, such as accountants and social workers. ${ }^{37}$ Motivated by a purported fear that these arrangements would undermine lawyers' independence, the American Bar Association has declared that this kind of deregulation would mark the end of the

35. For the role of law and politics in shaping lawyers' ethical obligations, see W. BRADLEY WENDEL, LAWYERS AND FIDELITY TO LAW (2010).

36. Public choice theorists have undermined a romantic notion of the law as the articulation of the will of the people, and it would at this point be naïve to equate law with public interest. See James M. Buchanan, Politics Without Romance: A Sketch of Positive Public Choice THEORY AND ITS NORMATIVE IMPLICATIONS 11 (J. Buchanan \& R. Tollison eds., 1984). As Bradley Wendel has argued, however, the law is an institution we have introduced to allow us all to live in harmony. WENDEL, supra note 35 , at 210 . It is the closest we have to common, agreed upon values. Id. Even if it is a product of lobbying power and particular interests, lawyers are nonetheless in a constant dialogue between their clients and the laws and procedures that their clients have agreed to obey. Lawyers are obligated to serve their clients within the bounds of the law and that latter restriction means something more than just what the client can get away with. W. Bradley Wendel, Government Lawyers, Democracy, and the Rule of Law, 77 FORDHAM L. REv. 1333, 1341-49 (2009).

37. As early as 1990 , lawyers warned against the dangers of multidisciplinary practice to a lawyer's independence. L Harold Levinson, Independent Law Firms that Practice Law Only: Society's Need, the Legal Profession's Responsibility, 51 OHIO ST. L.J. 229, 249, 262 (1990). The American Bar Association set up a commission in 1998 to explore the question of multidisciplinary practice. See AMERICAN BAR Association, Commission on Multidisciplinary Practice, http://www.americanbar.org/groups/professional responsibility/commission multidis ciplinary practice.html. The Commission recommended, "Lawyers should be permitted to share fees and join with nonlawyer professionals in a practice that delivers both legal and nonlegal professional services ... provided that the lawyers have the control and authority necessary to assure lawyer independence in the rendering of legal services." AMERICAN BAR ASSOCIATION, Commission on Multidisciplinary Practice, Report to the House of Delegates, Report, available at http://www.americanbar.org/groups/professional_responsibility/commission_multi disciplinary practice/mdpfinalrep2000.html. See also Bruce A. Green, The Disciplinary Restrictions on Multidisciplinary Practice: Their Derivation, Their Development, and Some Implications for the Core Values Debate, 84 MiNN. L. REv. 1115, 1128-32 (2000); DeStefano, supra note 10, at 2791-94; Nora Engstrom, Lawyer Lending: Costs and Consequences, 63 DePaUl L. REv. 377 (2014); W. Bradley Wendel, Alternative Litigation Financing and AntiCommodification Norms, 63 DEPAUL L. REV. 655 (2014). 
American legal profession as we know it. ${ }^{38}$ Many critics of the bar dismiss the notion of independence as so much empty rhetoric. ${ }^{39}$ They argue that the ABA is using this language, as it has always done, to promote and simultaneously mask the economic self-interest of its elite constituents. ${ }^{40}$ According to this critique, the Bar uses the term as a subterfuge to sustain unwarranted monopolies and control over the market. ${ }^{41}$ In recent years, as the global legal market has put pressure on the American legal profession to take a more flexible, creative approach, this particular debate has reached a fevered pitch. By exploring alternate meanings and uses of professional independence, this Article cautions those who oppose the ABA's approach to refrain from discarding the useful and beneficial aspects of independence along with the sometimes reactionary agenda that it has been used to support.

The question of a lawyer's independence also informs an age-old debate about how active a lawyer ought to be in directing and curbing the wishes of his client. Professional independence is key, in other words, in helping lawyers assess their role in protecting the interest of third parties, the community, and the integrity of the justice system as a whole. Lately, this debate has renewed vigor. Independence from clients allows lawyers to take a broader perspective, to view the long-term interests of the client alongside the well-being of the public. ${ }^{42}$ Others claim that this sort of independence undermines the client's autonomy and that lawyers ought to be independent in an almost opposite sense. If a lawyer is independent of a client, as the argument goes, then she does not need to take responsibility for the client's values or objectives. Even the most unpopular causes deserve legal representation and an independent lawyer can provide that representation because doing so does not involve an endorsement of the client's values or agenda. ${ }^{43}$ This debate assumes, like the one concerning multidisciplinary practice and outside ownership of law fims, that tile key issue is a lawyer's independence from the client.

38. John S. Dzienkowski \& Robert J. Peroni, Multidisciplinary Practice and the American Legal Profession: A Market Approach to Regulating the Delivery of Legal Services in the TwentyFirst Century, 69 Fordham L. Rev. 83, 85a88 (2000).

39. MORGAN, supra note 3.

40. Id.

41. This is the narrative that many historians have told about the rise of the legal profession in the twentieth century. See generally AUERBACH, supra note 6.

42. David Luban, LaWYers aND Justice: AN ETHICAL STUdy 148-77 (1988); Gordon, supra note 29, at 13; see William H. Simon, Ethical Discretion in Lawyering, 101 HaRV. L. REV. 1083, 1090-118 (1988) [hereinafter Ethical Discretion].

43. This version of independence is embodied in the Model Rules for Professional Conduct, Rule 1.2(b), which states, "A lawyer's representation of a client, including representation by appointment, does not constitute an endorsement of the client's political, economic, social or moral views or activities." MODEL RULES OF PROF'L CONDUCT R. 1.2(b) (2013) 
But at other points in history, the bar has emphasized that there are public passions, mob instincts, private interests, and factions that ought to be checked, and the lawyer stands perfectly poised to do so. ${ }^{44}$

Another understanding of professional independence concerns the lawyer's independence from the state. Independence in this iteration counters the dangers that arise when lawyers are too deeply beholden to the courts or the executive branch. The fear is that we will end up with a docile bar, unwilling to question the government, protect the rights of individuals, or challenge the legitimacy of government action when necessary. This notion of independence is part of what justifies professional self-regulation. It is built on the idea that the rule of law cannot exist without a separate class of lawyers policing the government to ensure that it behaves lawfully.

This Article offers context for the current debates. It serves as a reminder of what professional independence has meant in the past, and the purposes it might serve in the future. If we dispense with the notion of a profession that is unified in some aspect, we lose this capacity to discuss and shape lawyers' role. The idea of a coherent and useful professional identity becomes meaningless and obsolete. If we dispense with the notion of a lawyer's independence because it has been used in the past for selfish, destructive purposes, we also lose the possibility that it might be marshaled for productive goals as well. In addition, by emphasizing that the useful aspects of professional independence have emerged historically as a product of group identity, this Article offers new insight into contemporary debates about the lawyer's role.

\section{B. History of Professional Independence}

The idea of professional independence traces back to the Federalist Papers. ${ }^{45}$ In Federalist 35, Alexander Hamilton wrote,

Will not the man of the learned profession, who will feel a neutrality to the rivalships between the different branches of industry, be likely to prove an impartial arbiter between them, ready to promote either, so far as it shall appear to him conducive to the general interests of the society ${ }^{46}$

As Professor Aziz Rana has explained, Alexis de Tocqueville made this idea explicit when he theorized that the American legal profession constituted an American brand of aristocracy. ${ }^{47}$ In his travels to America

\footnotetext{
44. Gordon, supra note 29 , at $1-30$.

45. The Federalist No. 35, at 185 (Alexander Hamilton) (J.R. Pole ed., 2005).

46. Id.

47. Rana, supra note 14 , at 1669.
} 
in the 1820 s, Tocqueville wrote, that lawyers are by training, "arbiters between the citizens." 48 They provide a check on the passions of the mob, by curbing the blind and senseless immediate needs that would destroy the whole. ${ }^{49}$

So, it follows, lawyers should remain removed from clients to avoid association with any particular faction or agenda. By doing so, they would be able to maintain sound judgment and direct clients' desires toward socially productive ends. They would use their own judgment and in so doing prevent any single group-no matter how rich or powerfulfrom taking over the judicial process and harnessing the government for its own ends. ${ }^{50}$

The term independence derives from civic republican political thought, an ideology that defined the founders' theoretical framework and shaped much of America's initial political structure. ${ }^{51}$ At the center of this ideology was the commonwealth ideal, the commitment to the public good over any particular interest. In this worldview, the government had only one goal: to foster and promote the good of the community. ${ }^{52}$ In order to take part in the social and political world, an individual had to have sufficient means to think beyond his own narrow self-interest. $\mathrm{He}$ needed some degree of financial security to be free from the influence or sway of another. In republican political thought, independence from one's own immediate needs and from the demands of others could only be obtained when a citizen was wealthy enough to be free from selfinterest and could act to benefit the entire community instead of himself or some segment of society to which he belonged. ${ }^{53}$ But independence was something more than wealth or land ownership. It was also a quality of mind, an aspect of character that insulated an individual from outside pressure. Significantly, republicanism assumed that any kind of skill or training, like land ownership, could enable someone to be independent. ${ }^{54}$

According to republican theory, an independent member of society could exercise virtue because he could provide for his own basic material needs. The virtuous citizen would subordinate his own self-interest to the good of the public. This civic devotion, critical to the well-being of the republic, comprised the only true sort of freedom - the freedom from the bonds of immediate self-interest, the freedom to deny one's own selfish

48. See Alexis De ToCQueVILle, Democracy In AmeriCA 264 (George Lawrence trans., J.P Mayer ed. 1988).

49. Id.

50. Gordon, supra note 29, at 15.

51. GoRdon WOOd, THE CREation of THE AMERICAN Republic, 1776-1787, at $46-90$ (1969) [hereinafter CREATION].

52. Id. at 54.

53. Id.

54. Gordon Wood, The Radicalism of the American Revolution 178-79 (1991) [hereinafter RADICALISM]. 
demands for the sake of larger community. ${ }^{55}$ The central goal of the republican government was to ensure and promote virtue among its independent citizenry. ${ }^{56}$

Republican political thought was not new at the founding and it was not necessarily democratic. ${ }^{57}$ In the seventeenth century, most political theorists assumed that only the landed gentry possessed sufficient independence to exercise virtue. America was born in a different spirit but as James Madison explained, a system of checks and balances was necessary to ensure that the republic was not as vulnerable as it might otherwise be to the inevitable lapses in virtue. ${ }^{58}$ For a while, most revolutionaries believed that ownership of even a small parcel of land could ensure independence. ${ }^{59}$ Virtue, as Thomas Paine noted, was not hereditary. ${ }^{60}$ It could be earned through education. ${ }^{61}$ As the young republic grew older, however, more political leaders feared the malicious and irrational whims of the masses. As they watched groups of citizens take over state legislatures and enact laws with what they perceived as divisive and factional agendas, leaders grew even more concerned about relying on the supposed virtue of the citizenry. ${ }^{62}$

Any just society would need to protect against this sort of tyranny. It could be tyranny of the powerful few or a tyranny of the mob. The only way to ensure against such domination was to promote a virtuous and independent citizenry capable of subordinating its own selfish will to the good of the community. ${ }^{63}$ But as time wore on, and the powerful demands of the populace grew to be a greater challenge, more people joined those who worried that the country needed a smaller, more elite group to guard against corruption. A landed gentry would have been a natural choice. But not in America. In America, some believed that lawyers could serve this role.

In Federalist 35, Alexander Hamilton suggested that even landowners had a motive to promote their own financial interest, but professionals were perfectly situated to direct individual energy toward the good of

55. Creation, supra note 51, at 61-62.

56. Linda K. Kerber, The Revolutionary Generation: Ideology, Politics, and Culture in the Early Republic, in THE NEW AMERICAN HISTORY 25-49 (Eric Foner ed., 1990); CREATION, supra note 51; see generally J.G.A. Pocock, The Machievellian Moment: Florentine Political Thought and THE ATLANTIC Republican TRAdition (1975).

57. See CREATION, supra note 51, at 60-61.

58. THE FEDERALIST No. 55, at 300 (James Madison) (J.R. Pole ed., 2005).

59. RADICALISM, supra note 54 , at $178-79$.

60. Id. at 181 .

61. Id.

62. See generally RADICALISM, supra note 54; BERNARd BAILYN, THE IDEOlogical ORIGINS OF THE AMERICAN REVOLUTION (1967).

63. CREATION, supra note 51, at 68 . 
all. ${ }^{64}$ In hindsight, many would surely disagree with his premise, but Hamilton explained that, as a class, "the learned professions ... form no distinct interest." ${ }^{\prime 65}$ As such, they could ensure against the domination of any one faction and direct each person's energy toward the good of all. As Tocqueville concluded, the education and training of lawyers perfectly suited them for this task. ${ }^{66}$ Lawyers, a new democratic - or at least meritocratic-aristocratic class, would see to it that the general population acted for the good of all rather than for themselves as individuals or for some faction with its own particular agenda. The mastery of the science of the law, the learning, and the education suited lawyers for leadership. They would be close to the people, enmeshed in the people's everyday problems, yet never blinded by them. Lawyers would prove a perfect check on the passions of the people, preventing the kind of tyranny that republicanism anticipated and dreaded. Thomas Jefferson echoed the sentiment. ${ }^{67} \mathrm{He}$ imagined a "natural aristocracy," a class of wise statesmen who would guide the population toward its best course. ${ }^{68}$ Unlike the landed gentry in Britain, this group would be chosen by merit. ${ }^{69}$

As the country grew older, lawyers picked up on the theme. George Sharswood, whom some have called the father of professional ethics, argued that lawyers must serve a leadership role because through argument, interpretation, and counseling, lawyers bring the government "home so nearly to every man's fireside." ${ }^{70}$.David Hoffman, another influential founder of American legal ethical discourse, similarly elaborated the role of lawyers as caretakers and guardians of American democracy. ${ }^{71}$ Hoffman made explicit the assumption underlying Alexander Hamilton and De Tocqueville's expression; it was professional expertise that situated lawyers to serve the good of all. ${ }^{72}$ It was their training and the scientific nature of the law. So, independence

64. The Federalist No. 35, at 185 (Alexander Hamilton) (J.R. Pole ed., 2005).

65. Id.

66. Gordon, supra note 29 , at 14-20.

67. Letter from Thomas Jefferson to John Adams (Oct. 28, 1813), in 1 THE Founders' CONSTITUTION 568-69 (Philip B. Kurland \& Ralph Lerner eds., 1987), cited in Rana, supra note 14 , at 1676 n.36.

68. Id.

69. Id.

70. George Sharswood, An Essay on Professional Ethics 31 (1834).

71. Russell G. Pearce, Lawyers As America's Governing Class: The Formation and Dissolution of the Original Understanding of the American Lawyer's Role, 8 U. CHI. L. SCH. Roundtable 381, 389-91 (2001); Perry Miller, The LifE Of THE Mind in AMERICA: From tHE REVOLUTION TO THE CIVIL WAR 109 (1965). Some place the lawyer's rise to social prominence later, after the Civil War. Bruce A. Kimball, The True Professional ideal in America: A HISTORY 107-08 (1995).

72. David Hoffman, A Course OF Legal Studies (1817). 
in this new iteration was no longer based on land ownership or material wealth, but rather knowledge, learning, and science. It was this special training that lent the American legal profession its unique ability not only to subordinate its own interests but also to guide others to do the same. ${ }^{73}$

Historians have catalogued lawyers' decline from this exalted position. The narrative explains that they abandoned their role. Captives of their clients' interests, lawyers would do anything for a fee. The criticism and sense of betrayal poured in almost as soon as the rhetoric elaborated lawyers' exalted position in society. ${ }^{74}$ Some said it was the use of retainers, which make lawyers too closely beholden to a particular client's interest. ${ }^{75}$ Or perhaps the dominance of the corporate bar at the turn of the twentieth century led to lawyers' decline.$^{76}$ Others blamed it on diversity ${ }^{77}$ or suggested it was the 1960s with its emphasis on individualism and anti-elitist sentiment. ${ }^{78}$ Recently, Professor Norman Spaulding has cast doubt on the entire thesis, suggesting that lawyers never assumed the position of civic leaders in the first place. ${ }^{79}$ They were always practitioners devoted primarily to their clients' ends. ${ }^{80}$

As interesting as the debate on the so-called declension thesis may be, for my immediate purpose, it hardly matters. What does matter is that the rhetoric existed once and still does. We are left with an accumulation of language and ideas over time. Some amalgamation that at a very high level of generality goes something like this: Lawyers are a critical component of a modern democracy because their training, experience, or devotion to the law situates them to direct private passions and particular interests toward a socially productive goal, which will benefit everyone in the end. Their role as lawyers places them at a remove from clients and distances them from government. By definition, lawyers bring

73. Id.; Russell G. Pearce, Rediscovering the Republican Origins of the Legal Ethics Codes, 6 GeO. J. LeGal ETHICs 241, 254-55 (1992) [hereinafter Rediscovering]. There has been some controversy about just how different Hoffman and Sharswood were. Some believe that Sharswood presented an approach to lawyering more consistent with the civic republican model, more focused on obtaining and promoting a common good. They argue that Hoffman was more focused on serving clients regardless of the ultimate good of their cause. Others counter that Sharswood and Hoffman were more similar than one would think. Both of them believed that a lawyer's goal was to achieve justice. Bruce Green, "Public Service Must Begin at Home": The Lawyer as Civics Teacher in Everyday Practice, 50 WM. \& MARY L. Rev. 1207, 1228-29 (2009).

74. KRONMAN, supra note 4 , at 4.

75. Robert Gordon, The Citizen Lawyer: A Brief Informal History of a Myth With Some Basis in Reality, 50 WM. \& MARY L. REV. 169, 187-88 (2009).

76. Gordon, supra note 29 , at 58-59.

77. KRONMAN, supra note 4, at 165-383.

78. Russell Pearce, The Legal Profession as A Blue State: Reflections on Public Philosophy, Jurisprudence, and Legal Ethics, 75 FORDHAM L. REv. 1339, 1342, 1359-60 (2006).

79. Norman Spaulding, The Myth of Civic Republicanism: Interrogating the Ideology of Antebellum Legal Ethics, 71 FORDHAM L. Rev. 1397, 1397-99 (2003).

80. Id. 
government into the interstices of individual lives. As such, they can shape the way individuals interact with the public, while making sure that the agencies of government do not overstep their bounds as well.

But lawyers are subject to corruption. The profession is a weak and precarious guardian of the commonwealth. The rhetoric of degeneration and decline is, in fact, built into the civic republican theory of political growth. Civic republicanism embraces a cyclical view of history: virtue leads to wealth, and wealth inevitably breeds corruption, devolution, and the destruction of virtue. So, it is no surprise that the notion of sickness, decline, and imminent death plays its part in the language of the professional role as well. ${ }^{81}$

While the question of professional decline is clearly an important one, which has preoccupied historians and scholars for quite some time, I am more interested in how the rhetoric of a lawyer's independence, including the language of betrayal and broken promises, has been used over time. I am interested in whether this rhetoric is something worth maintaining or whether we can afford, as some scholars have suggested we should, dispense with it entirely.

It is easy to dismiss the early praise of lawyers' independence as selfcongratulatory rhetoric and no doubt that is, to some extent, true. It is worth noting, however, that the language lawyers invoked to describe their role in the polity included religious imagery and images of war. Thus, in the 1880s on the eve of the founding of the American Bar Association, lawyers referred to themselves as "priests at the altar of justice." 82 Lawyers, they explained, go into battle and wage war for the well-being of all. ${ }^{83}$ The rhetoric (similar to that of civic republicanism) shows that the profession, for a time, at least, viewed itself as a kind of secular priesthood or army of elite officers.

The language of independence made its way from Hoffman and Sharswood into the Canons of Professional Responsibility. ${ }^{84}$ In 1908, the then-young American Bar Association decided to commit some of its ethical principles to writing. ${ }^{85}$ These standards were aspirational. As Professor Russell Pearce has demonstrated, the Canons translated the republican political vision into a set of hopes or standards for the legal profession. The Canons officially hoisted lawyers into the role of

81. See Rayman L. Solomon, Five Crises or One: The Concept of Legal Professionalism, 1925-1960, in LaWYers' IdEals/LaWyers' PraCtiCes: Transformations IN THE AMERICAN LEGAL Profession 144-45 (Robert L. Nelson et al. eds., 1992). See generally PoCOCK, supra note 56.

82. Hon. Daniel Dogherty, Some Reflections on the American Bar, Its Integrity and Independence, 22 AM. L. REv. 177, 179 (1888).

83. Id.

84. Pearce, supra note 73 , at $267-70$.

85. Susan D. Carle, Lawyers' Duty to do Justice: A New Look at the History of the 1908 Canons, 24 LAW \& SOC. INQUIRY 1-44 (1999). 
guardians, protecting the common good from the intrusion and corruption of factional and particularized interests. ${ }^{86}$ For instance, Canon 30 stated that a lawyer "advances the honor of his profession and the best interests of his client when he renders service or gives advice tending to impress upon the client and his undertaking exact compliance with the strictest principles of moral law." ${ }^{87}$ Canon 15 noted that a lawyer "must obey his own conscience and not that of his client." $" 88$

The Model Code of Professional Conduct, adopted in 1970, many decades after the original Canons, provided the first set of enforceable rules along with a more detailed set of aspirations, labeled "ethical considerations." 89 The idea of a lawyer's professional independence shaped many of the rules and standards. A lawyer, for instance, was not supposed to assert a belief in the justness of a client's cause. ${ }^{90}$ As Professor Robert Gordon has explained, this is because there is a core of a lawyer that cannot be bought and sold. ${ }^{91}$ A lawyer's political and moral convictions remain apart from the representation, arming the lawyer with the capacity to counsel, urge, direct the client or if need be, resign from the representation..$^{92} \mathrm{~A}$ lawyer similarly is not bound to take any case and can draw from arenas other than the law in counseling his or her client. ${ }^{93}$

In the 1950s, the independence of lawyers found new champions in the functionalist sociologists who saw the professions as necessary to articulate and promote shared values in a world that was becoming increasingly atomized and commercialized. ${ }^{94}$ But the celebration of expertise and specialized learning as the source of a disinterested capacity to direct society toward common values soon met a formidable critique. In the decades that followed, historians and sociologists attacked the functionalist view as naïve and paternalistic. Marxists and Weberian scholars demonstrated how the class of professionals-supposedly dedicated to the common good-had mostly promoted the interests of an elite few at the expense of women, ethnic, and racial minorities. The entire rhetoric of professionalism masked the deep schisms in society, the

86. Id.

87. Model Code of Prof'l Responsibilty Canon 32 (1908).

88. Id. at 15 .

89. Model Code OF PROF'L RESPONSIBILITY (1970).

90. Id. DR. 7-106(c)384; R. 3.4(c); CANONS OF PROF'L ETHICS OF THE AM. BAR ASSOC., Canon 15.

91. Robert W. Gordon, The Independence of Lawyers, 68 B.U. L. REV. 1, 13, 31-32 (1988).

92. Model Rules of Prof'l Conduct R. 3.4(e) (2013). See also id. R. 1.16(b)(4) (allowing the lawyer to withdraw when the "client insists upon taking action that the lawyer considers repugnant or with which the lawyer has a fundamental disagreement"). See Gordon, supra note 29 , at $11-12$.

93. MOdel Rules of PROF'L CONDUCT R. 2.1. (2013).

94. Gordon, supra note 29, at 17-18. See also Roiphe, supra note 9, at 33-39 (defending the often maligned functionalist sociologists). 
incurable ills of a capitalist world. Professionals disguised power and oppression as science and fact, dangerously hiding their own agenda beneath the guise of objectivity. ${ }^{95}$

The republican ideal of a disinterested independent lawyer, while no longer popular, seems to have sustained the assault that began in the late sixties and seventies on the professional project. The idea still makes its way into Professional Responsibility classes and bar addresses. ${ }^{96}$ The organized bar still uses the notion of professional independence to resist regulatory changes or promote agendas. ${ }^{97}$ The fact that the concept of professional independence is so resilient, however, does not alone justify its continued worth or power.

\section{Professional IndePENDENCE IN CONTEXT}

Historians have chronicled the famous invocations of professional independence. They have marked the origins of the term as I have done and noted how it made its way into the rules of professional responsibility. But there is a long stretch of history in between. What became of the concept of a lawyer's independence? Robert Gordon in his article on the subject sought to understand what conditions promote independence. ${ }^{98}$ Others, as I have noted, have simply dismissed the concept as so much empty (and dangerous) rhetoric. ${ }^{99}$

Rather than fill in the story by describing the progression of the notion through the past two centuries (a Herculean task), this section has a much more modest goal. It will recount three different episodes in the history of the legal profession, in which a lawyer's independence proved an important theme. By doing so, it serves as a reminder. As scholars and regulators point to the abuses committed in its name, it is worth remembering that the notion of professional independence has a more illustrious past. By unearthing these debates, this Part also provides a warning. If we dispense with the idea of a separate legal profession, if we give up a sense of professional identity, and with it a notion of a lawyer's independence, we give up the possibility of this sort of discourse. Finally, taken together, the three episodes frame professional independence not as an ideology, but as an aspect of identity. By doing so, the history offers a new frame for the ongoing debate over the profession's relationship to democratic ends.

\footnotetext{
95. Roiphe, supra note 9, at 46-51.

96. MACCRATE REPORT, supra note 15 , at $118,135$.

97. MORGAN, supra note 3, at 40-49.

98. Gordon, supra note 29, at 29-67.

99. See supra notes $3-4$ and accompanying text.
} 


\section{A. Defending the Robber Barons}

Every era has its villains. In the late nineteenth century, or the Gilded Age, it was the robber barons. Robber barons, like Jay Gould and "Diamond" Jim Fisk, were corrupt businessmen, infamous for amassing huge sums of money at the expense of the public and ruthlessly destroying competition that stood in the way of their fortune. ${ }^{100}$ Industrial capitalism had raced into the modern age after the Civil War and the robber barons were quick to take advantage of a regulatory framework that had not yet caught up. ${ }^{101}$ They paid their workers poorly and kept them in notoriously dangerous conditions. ${ }^{102}$ They artificially suppressed prices until they could buy out their competitors and create monopoly rates for their wares, at which point they would raise the prices and reap the rewards. ${ }^{103}$

History has moderated the view of these wealthy capitalists. Perhaps they were not quite as evil as they seemed at the time. They were, after all, just a product of an economy in the midst of turbulent change. Some have even argued that they brought a degree of order to the chaotic market. ${ }^{104}$ But at the time, in the Gilded Age, as the country was struggling with its own ambition, they were seen by many as representative of all that had gone wrong in American society.

In the midst of this, in 1868, the well-known and controversial lawyer, ${ }^{105}$ David Dudley Field represented Daniel Drew, Jay Gould, and Jim Fiske, three of the most notorious industrial capitalists of the time, in their struggle with Cornelius Vanderbilt for control of the Erie Railroad. ${ }^{106}$ Gould and Fiske were trying to gain control over Albany and Susquehanna Railway to obtain a growing monopoly hold on access to

100. See generally Matthew Josephson, The Robber Barons: THE Great american Capitalists, 1861-1901, at 32-50 (2011); Tim MCNeEse, The RobBer Barons and the SHERMAN ANTITRUST ACT: RESHAPING AMERICAN BUSINESS 48-65 (2009).

101. MCNEESE, supra note 100, at 13-67.

102. Id.

103. Burton W. Folsom, JR., The Myth of THE RobBer Barons: A New LOOK AT THE Rise OF BIG BUSINESS IN AMERICA 121-35 (1987).

104. Id.; Alfred D. Chandler, JR., The Visible Hand: The Managerial Revolution IN american Business (1977); Allan Nevins, John D. Rockefeller: The Heroic Age of AMERICAN ENTERPRISE (1940).

105. David Dudley Field, the son of a New England minister and brother of the United States Supreme Court Justice, Stephen Field, was a well-established and successful attorney. He was, perhaps, most known and most reviled for his passionate critique of the technicality of the common law and his tireless but ultimately failed fight for codification in New York. David Dudley Field, Reform in the Legal Profession, in THE LEgal MIND IN AMERICA: From INDEPENDENCE TO THE CIVIL WAR 285-95 (Perry Miller ed., 1962).

106. Charles F. Francis, Jr. \& Henry Francis, The Chapters of Erie and Other EsSAYS (1886); Charles F. Francis, Jr., The Erie Railroad Row, 3 AM. L. REv. 41 (1868). 
the Northeastern states. ${ }^{107}$ Gould was doing the same with the market for gold. ${ }^{108}$ Field's decision to represent the robber barons was controversial. ${ }^{109}$

As if matters were not bad enough, in 1870, a committee of the Association of the Bar of the City of New York initiated an attempt to prosecute William "Boss" Tweed, the infamous corrupt head of the Democratic political machine in New York. ${ }^{110}$ After the committee refused his overtures to represent it in the matter, Field agreed to represent Tweed - an unpopular decision, to say the least. ${ }^{11}$

Field's choice, his decision, and the reaction of both bar members and the public illustrate how critical the notion of independence was to the conversation. Professional independence framed the debate between Field and the public about the proper role of lawyers in a democracy. This conversation proved especially useful as the country was adjusting to fairly dramatic changes in the nature of the industrial marketplace. There was no way to comprehend the idea of a professional duty to clients or to the public without it. It was not that professional independence provided the answer. It did not. But it made the dialogue possible. And the discussion, in turn, allowed the profession to evolve to meet, and in some way shape, the increasingly complex demands of a changing society.

In 1871, Samuel Bowles, the renowned journalist and editor of the Springfield Republican, published a letter condemning Field for his "professional association with notorious parties, with generally conceded corrupt schemes." 112 The author of the letter, clearly too offended to leave

107. Francis, supra note 106 , at $41-80$.

108. JosePHSON, supra note 100, at 143-46; Henry Adams, The New York Gold Conspiracy, in Charles F. Adams, Jr. \& Henry Adams, Chapters of ERIE, AND Other EsSays 100-34 (1871).

109. Michael Schudson, Private, Public, and Professional Lives: The Correspondence of David Dudley Field and Samuel Bowles, 21 AM. J. Legal HIST. 191, 196-97 (1977).

110. George Martin, Causes and Conflicts: The Centennial History of the AssOCIATION OF THE BAR OF THE CITY OF NEW YORK, 1870-1970, at 63-67 (1997).

111. Id. at 66.

112. The Duties and Rights of Counsel: A Conversation Between Samuel Bowles and David Dudley Field, 3 ALB. L. J. 81, 82 (1871) [hereinafter The Duties and Rights of Counsel]. The letter, reprinted in the N.Y. Times in full, read:

David Dudley Field, though hardly old enough to be called a veteran is one of the ablest lawyers in New York, and has by far the largest practice. His receipts as counsel to the Erie Railroad alone are understood to have exceeded $\$ 200,000$ in a single year and his regular income is enormous. His connection with Fisk and Gould secures him the favor of Barnard and the other ring Judges, though it has destroyed his reputation as a high-toned lawyer with the public, while the bar always disliked him for his avarice and meanness. David Dudley Field is a strong free-trade advocate, and often presides at the meetings of the Reform Club. $\mathrm{He}$ is an authority on international law, and also a chief codifier of the present code of procedure of the state of New York. His reputation as a lawyer is based on his 
the debate with such an accusation, added that Field was the "king of the pettifoggers," a term that was as pejorative a stab at a lawyer as one could find at the time. ${ }^{113}$ Bowles apologized for the personal attacks but stood by the condemnation of his representation of Gould and Fiske: The reaction of your old friends in Western Massachusetts is one of "mingled sorrow and indignation at your professional associations with Fisk and Gould and their desperate schemes." 114

Field responded, "The storm of abuse that is poured upon me is really, however designed, an attack upon the independence of the bar." $115 \mathrm{He}$ explained, "They who hate a client fancy, in their folly, that if they can frighten his advocate they may destroy the client, not reflecting that they would thus weaken their own security." 16 Field sought to justify his position by invoking the independence of the bar. By representing an unpopular individual, Field argued, a lawyer is standing up for the law, the ability of the courts and the process to sort out justice. He is not standing with his client, vouching for his client, or as Bowles had suggested, endorsing the client's actions or beliefs. ${ }^{117}$

Field might have stopped there but instead he invoked Thomas Erskine, the British lawyer and politician, who famously defended Thomas Paine against accusations of seditious libel for his publication of the Rights of Man. ${ }^{118}$ In a much quoted phrase, Erskine explained his own controversial choice: "I will forever, at all hazards, assert the dignity, independence, and integrity of the English bar, without which impartial justice, the most valuable part of the English constitution, can have no existence." 119 So, perhaps, independence ensures the lawyer's distance from the client such that it secures the right of every man accused of a crime or wrongdoing to counsel. The lawyer, as Erskine went on to explain, is not the judge. He sits by his client, offers a defense, and lets the judge determine the correct result.

knowledge of technicality and once during a legal controversy with the late James T. Brady, the latter dubbed him the 'king of pettifoggers' which title has stuck to Field ever since.

Id. at 81. Editorial, Jim Fisk's Lawyers, N.Y. TIMES, Dec. 16, 1870 [hereinafter Fisk's Lawyers]. The correspondence was also printed in DAVID DUDLEY FIELD \& SAMUEL Bowles, THE LAWYER AND HIS ClienTS 1 (1871) [hereinafter FIELD \& BowLES].

113. FIELD \& BowLES, supra note 112 , at 1 .

114. Id. at 2 .

115. Id. at 6 .

116. Id.

117. This understanding of independence resembles Model Rule of Professional Conduct 1.2(b) ("A lawyer's representation of a client, including representation by appointment, does not constitute an endorsement of the client's political, economic, social, or moral views or activities."). MOdel RULES OF PROF'L CONDUCT R. 1.2(b) (2015).

118. LEONARD W. LeVY, EMERGENCE OF A FreE Press 285-86 (1985).

119. Lloyd PAUl STRYKer, FOR THE DEFENSE (1947). 
But Bowles disagreed. Erskine, he pointed out, was defending an idea, a noble cause. He was fighting for the freedom of the press, the right, as he went on to say, of the individual, "to seek to change the public mind by the conviction which flows from reasonings dictated by conscience." 120 Independence, according to Bowles, did not imply the right of the lawyer to represent just anyone regardless of his conduct. ${ }^{121}$ Offended by the comparison between Field and Erskine, Bowles insisted that Field was not a hero standing up for a client who expressed unpopular ideas, but rather a lawyer who was lending his significant skills to powerful individuals who had brought "temporary disorder to the financial condition of the country, and spread ruin, with a wanton hand among its people." 122 Field was abusing technicalities in the law to help these sorts of men avoid justice. Even the worst of villains deserve representation, but why do they deserve Field's particular talents? ${ }^{123}$

In response, Field countered with his understanding of independence: A lawyer is not responsible for his clients' conduct but rather for the "manner in which he conducts their causes." 24 He explained, "I know no better general rule than this: that the lawyer, being entrusted by government with the exclusive function of representing litigants before the courts, is bound to represent any person who has any rights to be asserted or defended." 225 But Bowles had a different notion, insisting that Field had "offended the moral sense of the public." ${ }^{26}$ Extrapolating from what he considered journalists' ethics, Bowles concluded that Field's view was simply wrong. ${ }^{127}$

The New York Times agreed with Bowles. ${ }^{128}$ In 1870 , the paper ran an editorial attacking the lawyer's choice to defend the Erie "villainies." 129 The paper dismissed the notion that it is the duty of the lawyer to accept all cases offered them insisting that all lawyers discriminate in their practice. ${ }^{130}$ In response to a defense in the New York Herald Tribune, the editorial staff of the New York Times commented that representing Fisk was not the same as representing an accused murderer. ${ }^{131}$ By representing

120. Id.

121. See id.

122. The Duties and Rights of Counsel, supra note 112, at 84 .

123. For a contemporary collection of essays addressing this problem, see HOW CAN YOU RePRESENT THOSE PEOPLE? (Abbe Smith \& Monroe H. Freedman eds., 2013).

124. The Duties and Rights of Counsel, supra note 112, at 88.

125. Id. at 84 .

126. The Correspondence of Mr. David Dudley Field \& Mr. Samuel Bowles, N.Y. TIMES, Jan. 30,1871 , at $1-2$.

127. Id.

128. Fisk's Lawyers, supra note 112.

129. Id.

130. Id.

131. Editorial, Mr. David Dudley Field's Case, N.Y. TIMES, Dec. 21, 1870. 
Fisk and his cohort, Field was assisting his clients in committing new crimes, in continuing to defraud shareholders, bribe lawmakers, and harm the public. Fisk was "determined to persevere in a course of cheating and robbery" and the lawyers were advising him on how to "dodge" the law as they did so. ${ }^{132}$ The New York Times insisted in editorial after editorial that what set Field apart from criminal defense lawyers was that he entered the court "in suits in which his clients are known to be in collusion with the judge." 133

In a series of articles, the left wing paper, The Nation, like the New York Times, sided with Bowles. It criticized Field, while elaborating a more robust role for the lawyers. The editorial explained that when lawyers defend individuals accused of a crime, they are representing not only the interest of their client but also "the well[-]being of the community in ensuring that every criminal is convicted through proper means." 134 It explained, however, that if the "bench is in a league with the dishonest" then "any lawyer who carries a dishonest man's case before the bench does ipso facto connive at the fraud." 135 That situation, the Nation proclaimed, has arisen in New York. The article concluded that Fisk and Gould's claim to legal assistance ought to be balanced by the "higher claims of public morality" because "their power ... [had] become so great as to rise them to all intents and purposes above the courts and the legislature." 136

The Nation was not the only publication to respond to the correspondence between Field and Bowles. Nor did it articulate the only view. George Ticknor Curtis, a Massachusetts lawyer and politician, defended Field in a long and technical recitation of the complex facts of the dispute. ${ }^{137}$ Francis Barlow wrote three letters, originally printed in the New York Herald Tribune, taking the opposite view. ${ }^{138}$

The debate might sound familiar. It is strikingly similar to the outcry over Charles Stimson's public statement that corporate executives ought

132. Id.

133. Editorial, David Dudley Field: More About His Connection with the Erie Suits, N.Y. TIMES, Mar. 10, 1871.

134. Forensic Ethics, NATION, Jan. 26, 1871, at 56.

135. Id. This is essentially the argument that William Simon makes. Simon argues that lawyers can only ethically represent their clients in an adversarial way with no regard for the ultimate justice of the cause or the outcome if the system is working perfectly. If, however, the institutions and procedures are defective then that sort of attitude toward representations would only result in the exacerbation of already skewed results. Ethical Discretion, supra note 42 , at 1090-119.

136. Forensic Ethics, supra note 134, at 57.

137. See George Ticknor Curtis, An InQuiry Into THE Albany \& Susquehanna Railroad Litigations of 1869: AND Mr. David Dudley Field's CONNECTION Therewith (1871).

138. Francis C. Barlow, Facts for Mr. David DUdley Field (1871). 
to force prestigious law firms to choose between their lucrative retainers and representing accused terrorists. ${ }^{139}$ While the notion of independence does not present an easy solution, it does provide a language for the argument. This was, at heart, a debate about the meaning of the independence of the bar. Field invoked the term to mean that lawyers are independent of their clients so that a legal representation never involves a personal endorsement of the client's activities or values. By defending a client or championing his cause, the lawyer is nobly playing his part in the justice system. Bowles had a different idea, one that was perhaps closer to its meaning in civic republican discourse and one that certainly seemed more in tune with popular opinion at the time. Independence from the client is not a good in itself. It is, rather, productive because it enables a lawyer to choose clients and represent them in a way that would help articulate, maintain, and promote a clear idea of what is good for all.

The correspondence between Field and Bowles illustrates how the notion of independence encouraged critics to think critically about the role that the legal profession played in the rise of business and the ills of the market. In representing clients, arguing about the meaning and scope of the law, lawyers were inevitably entangled in this central struggle. Independence gave them the language to address and argue over how the profession and the legal system could best shape the future. Bowles insisted that lawyers had a direct role to play, by choosing clients and deciding how to represent those clients, in addressing the failures in the marketplace. Field agreed that lawyers played such a role but insisted that they did so by making sure that courts, law, and justice were accessible to all.

\section{B. The Legal Services Bureau}

In 1965, President Lyndon Johnson established the Office of Economic Opportunity (OEO) as a part of the Great Society designed to address poverty and racial injustice. ${ }^{140}$ The OEO established and funded legal service agencies throughout America. ${ }^{141}$ Prior to this radical initiative, the poor had to make do with the inadequate services provided by private charities and municipal governments. ${ }^{142}$ The OEO coupled its

139. Neil A. Lewis, Official Attacks Law Firms Over Detainees, N.Y. Times, Jan. 13, 2007.

140. EARL Johnson, JR., Justice \& Reform: The Formative Years of the OEO Legal Services Program 41 (1974).

141. Id.

142. ABEL, supra note 4 , at 128 . Prior to 1875 , legal services were largely left to the voluntary activities of unorganized lawyers. Roger C. Crampton, Crisis in Legal Services for the Poor, 26 VILL. L. REV. 521, 523 (1981). These organizations were underfunded and disorganized. Warren E. George, Development of the Legal Services Corporation, 61 CORNELL L. REv. 681, 682 (1975). In the late nineteenth and early twentieth centuries, voluntary organizations grew up in the inner cities to help coordinate these charitable acts. Crampton, supra, at 523-24. The nation 
objective of providing legal assistance to the poor with a more radical agenda to achieve social justice through law reform, income redistribution, and the political organization of the poor. ${ }^{143}$

The organized bar reluctantly supported OEO, voicing its concern about how the federally funded initiative threatened lawyers' independence. $^{144}$ How could lawyers adequately challenge the government if it paid their salaries? ${ }^{145}$ The Bar's fear turned out to be unfounded. From the outset, state governments expressed panic over the extent of the organization's independence. ${ }^{146}$ These young attorneys were aggressive and resourceful. They challenged the government in court battles, which threatened to dismantle the status quo. ${ }^{147}$ The OEO affiliated state organizations faced political battles. Legislatures threatened to cut their funding. ${ }^{148}$ States introduced bills to forbid these organizations from suing the state government. ${ }^{149}$

Like Dr. Frankenstein and his monster, the federal government similarly sought to curb what it saw as the excessive conduct of these organizations. By the early 1970s, President Nixon began to chip away at the OEO organizations. ${ }^{150}$ To protect the embattled organizations, congressmen sought to establish a federal Legal Services Corporation through legislation with a broad mandate to address equal access to justice. The law, which ultimately passed in 1974, established a federal board of experts to oversee what was supposed to function as an independent organization. ${ }^{151}$ In its initial iteration, the LSC was designed to address large structural problems facing the poor as well as societal issues that deepened the divide between the wealthy and those in need. ${ }^{152}$ So, the initial crew of lawyers received two-year fellowships to think up innovative litigation, class actions, and legislative initiatives. ${ }^{153}$ It was not

did not really begin to address the problem of the unmet need for legal services until after the Supreme Court decided that indigent defendants in criminal cases were entitled to counsel. Gideon v. Wainwright, 372 U.S. 335 (1963).

143. Crampton, supra note 142 , at 524 .

144. JOHNSON, supra note 140 , at $43-64$.

145. Id.

146. George, supra note 142 , at $684-85$.

147. Id.

148. Id. at 684 .

149. Id.

150. Bryant Garth, Neighborhood Law Firms for the Poor: A Comparative Study of ReCENT DeVElopments IN Legal AID AND IN THE Legal Profession 41 (1980); Lawrence J. Fox, Legal Services and the Organized Bar: A Reminiscence and a Renewed Call for Cooperation, 17 YALE L. \& POL'Y Rev. 305, 309 (1998).

151. 42 U.S.C. § 2996b(a) (1994); Charles J. Cooper \& Michael A. Carvin, The Price of "Political Independence": The Unconstitional Status of the Legal Services Corporation, 4 B.U. PuB. INT. L.J. 13, 13-16 (1994).

152. George, supra note 142, at 683-84.

153. Fox, supra note 150 , at 306-12; EARL S. JOHNSON JR., JUSTICE AND RfFORM: THE 
conceived, at first, primarily as a way to provide individuals with access to legal services like estate planning and divorces but rather a broad governmental initiative to enable creative legal approaches to the problem of poverty in the United States. ${ }^{154}$

At first the American Bar Association resisted the idea of a federally funded legal services organization. ${ }^{155}$ Particularly in the 1950s, the bar seemed concerned about turning our robust democracy into something that more closely resembled a communist state. The haunting presence of the Soviet Union in the 1950s fueled the debate. ${ }^{156}$ Even after the proposal, the Bar reserved support, expressing concern that the lawyers who represented clients against the interest of the lawyers' employer would lack the requisite independence. Despite its initial opposition, the Bar ultimately supported the proposal. Judge Jack Weinstein of the Eastern District of New York, explained:

There is always a danger that when government is funding a program, it will cut off funds when the attacks on government become effective. When government is controlled by a majority whose views differ substantially from the views of the minority, there is a possibility -- without an independent counterforce or series of forces such as those provided by independent lawyers-that there will be an explosive rending of the whole fabric of society. ${ }^{157}$

The fundamental issue then was how vulnerable a lawyer's independence was, how susceptible to decay under the proposed structural arrangement. ${ }^{158}$ In Judge Weinstein's view, the country had no

Formative Years of the OEO Legal Services Program (1974).

154. Fox, supra note 150 , at 306-12; JOHNSON, supra note 153.

155. The idea was around as early as 1950. The President of the American Bar Association denounced the proposal on the ground that it would threaten the independence of lawyers. Harold Gallagher, President's Page, 36 A.B.A. J. 210 (Mar. 1950) ("To serve clients and the public weal, lawyers must be free of bias and government control. With government subsidies come government control and the loss of freedom.").

156. Editorial, Legal Profession vs. Regimentation, 37 A.B.A. J. 103, 168 (Feb. 1951) (comparing a federally funded legal services program to the "state controlled legal profession behind the Iron Curtain."). See also Editorial, Legal Aid in New Jersey: The Answer to a Socialized Legal Profession, 36 A.B.A. J. 355, 356 (1950) (arguing against state funded legal aid because it compromises "independence.").

157. Comment, The Legal Profession Grids for the 1970s, 8 COLUM. J.L. \& SOC. ProBs. 75, $99(1971-72)$.

158. Powerful established interests do not like an independent bar and take any opportunity they can to hobble it. For example, regulated industries attempted to dismantle clinical education when the clinics started to represent clients who posed a threat on issues such as environmental justice. See David Luban, Taking Out the Adversary: The Assault on Progressive Public-Interest Lawyers, 91 CALIF. L. REv. 209, 236-41 (2003). Despite the David and Goliath like battle, the bar 
choice but to depend on the fact or the hope that professional independence was more an aspect of collective identity then something so easily undermined by the structure of a lawyer's employment. ${ }^{159} \mathrm{He}$ explained that he was forced to suspend his own skepticism because of how indispensable lawyers' independence was to a democratic government. ${ }^{160}$

As it wove its way through history, the greatest hope for the LSC was never truly met. Its vision was obscured by other things. The story of its decline has been told. The optimism of President Johnson's vision has certainly been lost. ${ }^{161}$ The role of the organized bar was initially less than heroic. It resisted the LSC but never proposed an alternative way to address the inequality in wealth or the unequal access to justice that is now a quite well accepted reality. ${ }^{162}$ Instead, the ABA claimed that the federally funded organization lacked independence. ${ }^{163}$ The bar worried that it would not truly be able to stand up to the government for the rights of the poor because it was beholden to Congress for its existence and funding. ${ }^{164}$

This is true. But there is more to the story. Lawyers' independence shaped the debate over the LSC and was a more productive concept than most have acknowledged. In 1972, Vice President Spiro Agnew launched his own personal battle over the LSC. ${ }^{165} \mathrm{He}$ accused the bureau of abandoning its mission of helping individual clients for a rogue social engineering mission. He argued that the LSC had become too aggressive in its assaults on the government:

seems to maintain its distance. This Article adds a dimension to this debate by arguing that the bar is able to stand up to these assaults from powerful interests because its strength (or independence) derives not from financial incentives but rather from a sense of group identity built over time.

159. See id.

160. The disagreement over whether lawyers could remain independent when employed by the government is essentially a dispute about whether independence is a personal or collective quality or a product of structural relations. In other words, some, like Judge Weinstein, believed that lawyers could remain independent regardless of who pays their bills. Others doubted this fact. See supra text accompanying notes 157-59. For a description of this difference in opinion as to the meaning of independence, see Harry B. Cohen, Book Review, A Southern Lawyer Looks at Legal Services. Barlow F. Christensen, Lawyer for People of Moderate Means: Some Problems of Availability of Legal Services, 24 VAND. L. REV. 433, 444 (1970). The author of the book claims that a legal services attomey paid by the government can maintain independent judgment. Id. The reviewer insists that a lawyer is beholden to his employer, regardless of his theoretical commitments. Id.

161. See generally ABEL, supra note 4.

162. See generally DeboraH L. RHODE, ACCESS to JuSTICE (2004).

163. Id.

164. Id.

165. Spiro T. Agnew, What's Wrong with the Legal Services Bureau, 58 A.B.A. J. 930,930 (1972). 
The Bar must lead a searching re-examination of the philosophical underpinnings of the national legal services program. Instead of ministering to the legal needs of their clients, legal services attorneys are seeking law reform and advancing their own social, economic and political theories. The legal services program was not created to give lawyers a chance to be social engineers on a grand scale. ${ }^{166}$

The Vice President proposed putting a censor in place to control the work of the legal aid lawyers. He wanted a public official to ensure that the legal service lawyers remained accountable to the public by answering to elected officials.

In a response, which was grounded in the notion of a lawyer's independence, William R. Klaus, a lawyer and leader in the bar association, argued: "The basic concepts upon which the Bar of the nation has supported the program from its beginning are being seriously challenged in a way that, carried to its logical conclusion, would threaten the independence of the entire profession." 167 Klaus explained that Vice President Agnew wanted the legal services lawyers to give in to control from the government. ${ }^{168}$ Agnew insisted that the only possible articulation of the public interest came from the public through its duly elected officials. Lawyers were an illegitimate counter-majoritarian force. The legal aid lawyers, according to the Vice President, were unaccountable. ${ }^{169}$ They were betraying their clients and crusading for their own ideological battle against poverty without consulting anyone before doing so. Klaus argued in response that the LSC lawyers were challenging the government to abide by laws and constitutional norms just as they should. That Agnew's attempt to control them from the top undermined their independence. ${ }^{170}$ It undermined the structure of the American government in which a group of trained educated lawyers sought to achieve justice, fight against interest groups and factions that inevitably control the elected officials, and force the government to comply with the principles underlying the law.

It took a far more concerted effort on the part of the government to de-fund LSC to impair the organization's advocacy in any significant way. In a debilitating Act in 1996, the government forbade LSC lawyers from participating in class actions, challenging welfare programs, or representing individuals charged with drug offenses in public housing

166. Id.

167. William R. Klaus, The Legal Services Program: A Reply to Vice President Agnew, 58 A.B.A. J. 1178,1178 (1972).

168. Id. at 1179 .

169. Agnew, supra note 165 , at $930-31$.

170. Klaus, supra note 167 , at 1178. 
eviction cases. ${ }^{171}$ It barred the lawyers from representing entire classes of clients, like aliens and incarcerated individuals. ${ }^{172}$ The government refused to fund LSC organizations that engaged in these activities even if they used non-government funds to do so. ${ }^{173}$

Of course, this dialog occurred against a rich and complex political backdrop. The early work of the LSC has since been criticized on many grounds. ${ }^{174}$ What is important for my purposes is that this dialog itself was valuable and that the debate revealed something about the resilience of professional independence. Whatever one might ultimately believe, the language of independence was necessary to counter Vice President Agnew's position. It was necessary to defend the work of these lawyers. Otherwise, what we are left with is unelected quasi-officials claiming the authority of legislation to promote their own individual agendas. The author cited the provisions of the code of professional conduct that articulated the lawyer's professional independence. ${ }^{175}$

The important irony in the history of the LSC is that the bar, initially concerned that government employed lawyers would lose their independence because the government employed them, ultimately defended the fierce and combative independence of those very same lawyers. Professional independence is more than a product of structural relationships. It exists despite incentives created by attorney fees. It is an aspect of professional identity that acts as a break on financial and other pressures that would normally affect an individual's choices.

\section{The McCarthy Era Loyalty Oaths}

The standard story of the Bar's conduct during the McCarthy era is grim. The American Bar Association stood by the government as it chipped away at civil liberties. The Bar cooperated with the House UnAmerican Activities Committee and United States Senator Joseph McCarthy, in their purges of those deemed to have left wing sympathies or even attenuated connection to the communist cause. Historians have recounted in horror how the national bar organization did not merely sit by without protest, it actively assisted in turning over some of its members and investigating others. It infused legal practice with trepidation, making even the most banal of left wing sympathies or representations the cause for suspicion. Historians and scholars have

171. Act of Apr. 26, 1996, Pub. L. No. 104-134, §§ 504(11), (15), 110 Stat. 1321-54 (1996).

172. Id.

173. David S. Udell, The Legal Services Restrictions: Lawyers in Florida, New York, Virginia, and Oregon Describe the Costs, 17 YALE L. \& PoL'Y REV. 337, 338 (1998).

174. Troy E. Elder, Poor Clients, Informed Consent, and the Ethics of Rejection, 20 GEO. J. LEGAL ETHICS 989, 1016-25 (2007).

175. MODEL CODE OF PROF'L RESPONSIBILITY DR 5 (1980); EC 2-28 (1980). 
repeatedly asked why the bar so quickly capitulated. ${ }^{176}$

No one, however, has asked why so many lawyers refused to cooperate, risking their reputation, licenses, and careers. It is certainly at least as remarkable that groups of lawyers, local and national, invoked professional independence and their identity as lawyers to take a stance against the pervasive conformism of the time. Historians who have focused on the official history of the organized bar have left this part of the story untold. Even the ABA, which represented only a small fraction of practicing attorneys, was deeply divided about the proper course during the McCarthy purges, with many lawyers bravely and publicly disagreeing with the organization's cooperation with the government. ${ }^{177}$

Different pockets within the profession successfully resisted the powerful tide. State and local bar associations quietly refused to cooperate. Established and prominent members of the ABA voiced opposition to the Bar's official position. These lawyers risked their careers and reputations to stand by attorneys who continued to represent those accused of having communist connections or sympathies. They were able to do so by drawing on a rich language and tradition of lawyers' independence. They justified their stance and recruited others to join them by invoking a professional identity that rested on the idea that the lawyers comprised an independent force in the state, a unique calling whose purpose was to resist pressure from popular factions and a government, which had overstepped its bounds.

This Part amends the traditional history of the legal profession by focusing on the issue of test oaths for lawyers. Loyalty oaths have long been a part of American history. Simple oaths of allegiance to the state and the constitution have been required of public employees for hundreds of years. Lawyers swore, as they do today, to uphold the laws and constitution of the state and federal government. But in the Cold War, states and the federal government began pushing for a loyalty oath with a far more explicit repudiation of the communist party and socialist cause. ${ }^{178}$

176. AUERBACH, supra note 6, at 3-13. For an exception, see Liu et al., supra note 5, at 978-88 (using the Chicago Bar Association as an example to show that there was never a consensus within the bar on how to treat the communist threat within the profession). Liu et al. argue that the Chicago Bar Association relied on "legalism," or issues of procedure, to criticize anti-Communist legislation in the 1950s despite internal political and ideological divisions. Id. My history of the loyalty oaths similarly shows that organized bars were able to invoke professionalism as a product of professional identity to take positions on controversial civil rights issues despite the diverse interests and political divisions.

177. ABEL, supra note 4, at 208-11. Abel explains that the ABA is disproportionately comprised of older white men who graduated from elite schools and practice in large firms. Id. at 211. Women and minorities tend to create and belong to alternate local bar associations, as do solo and small firm practitioners. Id. at 210.

178. M.J. Heale, McCarthy's americans: Red Scare Politics in State and Nation, 
Embracing the growing panic over radicalism, in 1950, the ABA resolved that all lawyers should have to take an oath and proclaim that they never belonged to or associated with a communist organization. This section recounts the history of how the bar-members of the ABA and state and local bar association-reacted to this proposal. In doing so, it corrects a history that has focused largely on the official proclamations of the American Bar Association, which accounted for only $25 \%$ of all practicing attorneys in the United States. It supplements a history that has omitted many powerful state and local organizations as well as the National Lawyers Guild, a radical organization of lawyers founded in 1937.

Furthermore, the ABA itself was divided. It did not comprise a uniform reactionary front, but rather a body of practicing lawyers with diverse views on the issue. And the Bar, for all its conformism, did acknowledge its own internal dissent. Despite its official support of the administration's fight against communism, the ABA proved relatively powerless to implement its proposal over the protest of lawyers both within the organization and outside it. The lawyers, who stood firm against test oaths, did so by drawing on a common identity defined critically by the notion of professional independence.

The notion of independence, the old civic republican vision, made its way into debates about whether the profession ought to stand up for its members who were disbarred for even attenuated association with left wing political associations. It informed the discussion over whether the Bar ought to take a stand collectively on civil rights issues. Like the discussion about David Dudley Field's representation of the Erie Railroad officials and the controversy over the LSC, this debate depended on professional identity, which in turn rested on an evolving understanding of professional independence.

One of the cornerstones of the traditional account of the Bar's ignominious retreat from principle during the Cold War is its response to loyalty oaths. In 1950, the Bar issued a resolution calling on the states to implement loyalty oaths, including an explicit repudiation of communism, for applicants to the bar and practicing lawyers. ${ }^{179}$

1935-1965, at 29 (2006); LAWRENCE M. FriedMan, AMERICAN LAW IN THE TWENTIETH CENTURY 334 (2002).

179. Proceedings of the House of Delegates, Sept. 18-22, 1950, 36 A.B.A. J. 948, 972 (1950). The resolution specifically stated that:

The legislature, the court or other appropriate authority of each state or territory and the District of Columbia, be requested to require each member of its Bar, within a reasonable time and periodically thereafter, to file an affidavit stating whether he is or ever has been a member of the Communist Party or affiliated therewith, and stating also whether he is or ever has been a member or supporter of any organization that espouses the overthrow by force or by any illegal or 
Mimicking a growing set of laws requiring oaths for public employees and union officials, the test oaths would have forced all applicants to the profession as well as practicing attorneys to attest that they had never belonged to the communist party or supported any organization that advocated the overthrow of the American government. ${ }^{180}$ If an individual answered affirmatively, it would trigger investigation and potential disbarment proceedings. ${ }^{181}$

While historians have made it seem as if there were a virtual consensus, opposition was strong and vocal. The House of Delegates voted to adopt ${ }^{182}$ the resolution with no debate and there was little discussion in the General Assembly. ${ }^{183}$ While it is impossible to discern the meaning of this silence, it would not be surprising given the climate if the delegates were afraid to voice opposition at the time. Despite the seeming support within the ABA, the position on loyalty oaths was far from unanimous. On December 17, 1950, 27 leaders of profession including Supreme Court Justice, Owen J. Roberts, and three former presidents of the ABA issued a statement in opposition to the Bar's proposal regarding loyalty oaths, which was printed in the $A B A$ journal. ${ }^{184}$ Again, it is unsurprising that most of those who signed the statement were firmly established in the profession, insulated (at least somewhat) from the consequences that others might face had they signed the petition.

In the months that followed the resolution, the ABA journal printed many of the opposing views. Vern Countryman, a professor at Yale commented, "[i]f lawyers ever become so intimidated by inquiries into their own loyalty that they fear to assert the constitutional rights of others in loyalty inquiries, then indeed our liberties will be lost." 185 Another member insisted,

unconstitutional means, of the United States Government, or the government of any of the states or territories of the United States; and in the event such affidavit reveals that he is or ever has been a member of said Communist Party, or of any such organization, that the appropriate authority promptly and thoroughly investigate the activities and conduct of said member of the Bar to determine his fitness for continuance as an attorney.

Id.

180. Id.; SAMUel WalKer, In Defense of AMERICAN Liberties: ATtORNEY OF THE ACLU 188-89 (1990).

181. The Proposed Anti-Communist Oath: Opposition Expressed to Association's Policy, 37 A.B.A. J. 123, 123 (1951) [hereinafter The Proposed Anti-Communist Oath].

182. Proceedings of the House of Delegates, 76 ANN. ReP. A.B.A. 527, 531-32 (1951) (explaining the way in which the ABA approved the loyalty oath resolution).

183. Proceedings of the House of Delegates, supra note 179, at 972.

184. The Proposed Anti-Communist Oath, supra note 181.

185. Vern Countryman, Loyalty Tests for Lawyers, 13 L. GulLD REv. 149, 157 (1953). 
Intellectual independence is being threatened in the U.S., by a growing readiness to label as communistic any opposition to any invasion of fundamental rights if the suggestion is made in the name of "loyalty." A tendency toward hysteria may explain this reaction in the public at large but it is shocking to see that it has found expression in the official organ of the profession whose purpose in society is so deeply grounded in objectivity of mind and fearless independence of expression. ${ }^{186}$

The author identifies independence as a defining characteristic of the legal profession, a characteristic that sets the profession apart and lends its members a special responsibility and political mission.

As HUAC was pushing to list the National Lawyers Guild as a subversive organization and have its members disbarred, the organization was fighting against the test oaths. In a conference on the topic, one editorial in the organization's periodical commented that test oaths:

would intensify the fear which already pervades the bar and create servility among lawyers. Fewer lawyers would feel free to exercise the ordinary rights of a citizen to participate in the discussion of controversial public questions, or associate freely with others when they know that in addition to the accepted social price of non-conformity, which they must pay for such activities, they may risk disbarment. Equally fewer lawyers would dare to discharge their professional responsibilities toward the defense of clients associated with unpopular causes when to do so might well result in creating animosities or evidence which could be used against them in a disciplinary action. ${ }^{187}$

The opposition cast its argument against test oaths as an effort to preserve the independence of the bar: "The lawyer's independence is an essential tool of his profession not only as an advocate in the courtroom but as a spokesman for the public interest and defender of popular liberty." 188 The central concern was independence not from the client but rather from the government. The fear, as the author of this report noted, was that test oaths would create a docile bar. It would turn the lawyer into "an apologist for the government rather than a defender of the Constitution." 189

The opposition to loyalty oaths was not only the brave if marginal

186. James E. Thomas, Disapproval of Oath for Members of the Bar, 37 A.B.A. J. 474, 474 (1950).

187. The Independence of the Bar, 13 LAW. GUILD REv. 158, 171 (1953).

188. Id.

189. Id. at 172 . 
response of a left wing legal organization. States, for the most part, declined to adopt test oaths of the type the ABA had proposed. Only a handful of states adopted test oaths and seventeen states explicitly rejected them. ${ }^{190}$ In practice, state and local bar associations may have given some nominal attention to inquiries into applicant's political affiliations, but most bar examiners reported that they had not denied any applicants to the bar on the basis of membership or affiliation with any left wing organization. ${ }^{191}$

In December 1950, the Association of the Bar of the City of New York issued a report and resolution opposing test oaths for lawyers. ${ }^{192}$ Reprinted in the $A B A$ Journal, the report insisted that the oath to uphold the laws and constitutions of the state and county, which every lawyer was already obliged to take, was sufficient. ${ }^{193}$ The resolution went on to explain that the test oath would "lessen the freedom of the Bar to accept the responsibility of representing unpopular causes."194 The Kings County Bar Association, the New York State Bar Association, and the Massachusetts Bar Association all issued similar resolutions opposing the specific anti-subversive loyalty oaths for lawyers. ${ }^{195}$ The ABA reported in an editorial the Kings County Bar Association official statement rejecting the oaths: "Whereas, such loyalty oaths would unjustly and falsely cast a suspicion of disloyalty on the entire legal profession, and divert the attention of Bar Associations from a constructive program of making secure the Bill of Rights, into the blind and dirty alleys of snooping, rumor-mongering and witch hunting." 196

While the initial reaction in the paranoid moment was often to strike out at lawyers with left wing sympathies, what is truly remarkable is not the capitulation but rather the fact that state bars and courts on the whole did not pursue "disloyal" lawyers. They did not share the official fervor of the national bar association or if they did, they did not act on it. In

190. Ralph S. Brown Jr. \& John D. Fassett, Loyalty Tests for Admission to the Bar, 20 U. CHI. L. Rev. 480, 483-97 (1952-1953). In 1950, a divided Court upheld the constitutionality of a provision of the Labor Management Relations Act of 1947, requiring union officials to file an affidavit declaring that they had never belonged to a communist organization in order to obtain recognition from the National Labor Relations Board. Am. Commc'ns Ass'n v. Douds, 339 U.S. 382 (1950). In 1952, however, the Supreme Court found that Ohio's test oath for public employees was unconstitutionally broad as it did not require that the lawyer know that the organization, which he supported, was listed as subversive or advocated the overthrow of the U.S. government. Id at 486 (citing Wieman v. Updegraff, 344 U.S. 183).

191. Brown \& Fassett, supra note 190, at 497.

192. The Proposed Anti-Communist Oath: Opposition Expressed to the Association's Policy, 37 A.B.A. J. 123, 124 (1951).

193. Id.

194. Id. at 125 .

195. Paul DeWitt, Bar Activities, 37 A.B.A. J. 475, 475 (1951).

196. Id. 
1920, Jacob Margolis, a well-known lawyer and Bolshevik activist, was disbarred in Philadelphia. ${ }^{197}$ Daniel O'Connell was disbarred in California after he was convicted under the 1917 Espionage Act that same year. ${ }^{198}$ In 1949 , five states proceeded against the lawyers who were charged with contempt in representing the defendants accused of violating the Smith Act. ${ }^{199}$ Only one of the five was ultimately disbarred ${ }^{200}$ In an era in which fear replaced trust and neighbors turned against each other, the profession in fact capitulated in sporadic symbolic acts, rather than in any systematic way. One Lawyers Guild member noted that the profession mostly realized that disbarment for representation of politically unpopular causes poses a "latent, potent menace to the independence of the bar."201

In 1955, the Florida Bar Association disbarred Leo Sheiner for failing to answer questions posed by the House Un-American Activities Committee of the U.S. Senate regarding his association with the Communist Party. ${ }^{202}$ In a summary opinion, the Florida Supreme Court ultimately held that the state had failed to meet its burden to prove that Sheiner was unfit to practice law. ${ }^{203}$ The National Lawyers Guild submitted an amicus brief to the Florida Supreme Court in support of Sheiner. ${ }^{204}$ The brief insisted that in order to protect civil rights and liberties, the "independence of the bar [must] be maintained intact." 205 The brief argued that, "[a]n intimidated bar, a bar coerced into political conformity, a bar subjected to harrying inquisitions will lack the courage and independence to fulfill one of its prime historical functions." 206

The American Bar Association took the opposite view. ${ }^{207}$ It explained,

197. Dreyfus \& Walker, supra note 200 , at 67.

198. Id. at 68.

199. Id.

200. Abraham J. Isserman was barred from practice in federal court and then disbarred by New Jersey in summary proceeding. 9 N.J. 269. The Bar Association of the City of New York instituted proceedings for the disbarment of Henry Sacher. He was initially ordered disbarred in the Southern District of New York but the Supreme Court remanded saying disbarment was too severe. Philadelphia investigated Louis $\mathrm{McC}$ abe and decided no action was appropriate. Michigan reached the same conclusion with regard to George Crokett. California similarly decided no action was appropriate for Richard Gladstein. Benjamin Dreyfus \& Doris Brin Walker, Grounds and Procedures for Discipline of Lawyers, 18 LAW. GUILD REV. 57, 68 (1958).

201. Id. at 69.

202. David L. Weissman, The Proceedings to Disbar Leo Sheiner: A Story of Judicial Maladministration, with a Portrait of Informer Joseph D. Mazzei, 16 LAW. GuILD REv. 137, 137 (1956).

203. Florida v. Sheiner, 112 So. $2 d 571$ (Fla. 1959).

204. Amicus Curiae Brief to the Supreme Court of Florida, reprinted in 15 LAw. GUILD REV. 11 (1955).

205. Id. at 11 .

206. Id. (citing Justice Black, The Lawyer and Individual Freedom, TN. L. REV. (1950)).

207. Id. at 23 . 
The rights of an individual - whatever his profession, calling, or office - might not be consistent with his professional or official status. Where consistent there is no problem, where, however, the individual rights are inconsistent, a choice becomes necessary either to forgo the individual right or relinquish the profession or office. $^{208}$

Homogeneity was clearly a priority. Diversity of views, in the Bar's official proclamation, was not only undesirable but also incompatible with professionalism and its mandates.

This disagreement occurred just as McCarthy was launching his attack on Fred Fisher, a young attorney who had worked briefly at the National Lawyers Guild when he was a law student, for associating with a group, which McCarthy characterized as a communist front organization. ${ }^{209}$ George Anastaplo, a World War II veteran and graduate of the University of Chicago Law School, was famously denied admission to the Illinois bar when he insisted that communist party members should be allowed to practice law in the United States and refused to deny his own affiliation. ${ }^{210}$ Though he had no known connection with left wing causes, Anastaplo believed that a democracy ought to tolerate those who advocated the violent overthrow of the government. He refused to answer the question about his political affiliations in an interview with the Illinois Committee on Character and Fitness. ${ }^{211}$ Ultimately, his case made its way to the United States Supreme Court, which upheld the decision to deny Anastaplo's admission to the bar. ${ }^{212}$ In dissent, Justice Black insisted that the decision threatened the independent bar. ${ }^{213}$

208. Id. at 28 .

209. For an account of this incident, see AUERBACH, supra note 6, at 237.

210. In re Anastaplo, 121 N.E.2d 826, 827-28 (Ill. 1954), cert. denied, 348 U.S. 946 (1955), reheard, 163 N.E.2d 429 (III. 1959), aff'd, 366 U.S. 82 (1961).

211. Id.

212. Id. at 93 .

213. Id. at 114-16. Black wrote:

It is such men as these who have most greatly honored the profession of the lawmen like Malsherbes, who, at the cost of his own life and the lives of his family, sprang unafraid to the defense of Louis XVI against the fanatical leaders of the Revolutionary government of France-men like Charles Evans Hughes, Sr., later Mr. Chief Justice Hughes, who stood up for the constitutional rights of socialists to be socialists and public officials despite the threats and clamorous protests of self-proclaimed superpatriots-men like Charles Evans Hughes, Jr., and John W. Davis, who, while against everything for which the Communists stood, strongly advised the Congress in 1948 that it would be unconstitutional to pass the law then proposed to outlaw the Communist Party-men like Lord Erskine, James Otis, Clarence Darrow, and the multitude of others who have dared to speak in defense of causes and clients without regard to personal danger to themselves. 
The organized bar hardly hesitated in support of the government's purge. It joined the effort with enthusiasm. But the decision was not unanimous. Lawyers and judges, who resisted and criticized, used the language of independence to condemn McCarthy and the official arm of the profession. In the case of Fisher, it worked.

\section{Salvaging the Notion of Professional Independence}

This Part uses the history of the profession and professional independence in particular as a reminder of how important professional independence has been in preserving and fighting for American democratic values.

The current pressure to race into the future, the fear that the bar will act (as it has done so often in the past) in a protectionist, monopolistic way, has led to a growing sense that professional independence-like much of the professional project-is merely subterfuge. ${ }^{214}$ It is a rhetorical flourish that allows lawyers to dress self-interested policies as publicly-minded positions. ${ }^{215}$ Scholars are understandably eager to align themselves with innovation over stagnation, but in their eagerness, they may forget that professional independence is complex. It is precisely its mutability that has allowed the concept to be so valuable and yet so dangerous in the past. Reconceived, the notion can continue to be critical in the future without serving reactionary ends. The profession has an obligation not to shape its ideals to suit a changing market and preserve the aspects of the past that serve a vital function.

Ironically, the same features of the changing marketplace for legal services that jeopardize professional identity and the concept of independence may also make the notion even more critical in the future. The global legal community is diverse. It is comprised of lawyers from countries of all sorts with different values and different relationships between the bar and the state. As American lawyers work more closely with their counterparts in other countries and national boundaries erode, it is even more important to discern what it is about our tradition that is essential. Otherwise, the good qualities of the American legal profession might well cave under the global pressure to conform and the market

The legal profession will lose much of its nobility and its glory if it is not constantly replenished with lawyers like these. To force the Bar to become a group of thoroughly orthodox, time-serving, government-fearing individuals is to humiliate and degrade it.

Id. at 116.

214. MORGAN, supra note 3, at 19-40.

215. Id. 
pressure to provide inexpensive services. ${ }^{216}$

On a fairly simple level, this Article serves as a reminder that professional independence in its many iterations has played an important role in American democracy. ${ }^{217}$ It stands for valuable propositions-the right of lawyers to represent clients with whom they do not agree to protect liberty, the duty of lawyers to choose clients carefully with a sense of their own role in defining and preserving the values of the community, ${ }^{218}$ the principle that lawyers must not be controlled by the government, the idea that the bar can take a position on controversial social issues regardless of the beliefs of individual clients - to name just a few. While it is impossible to deny the internal tensions between the different conceptions, this fact does not render the concept incoherent.

These three examples - the representation of the robber barons, the founding of the Legal Services Corporation, and lawyers' reaction to the McCarthy Era test oaths-are episodes in the history of the profession. They cannot be used to demonstrate a clear development in the notion of professional independence in America. What these examples can do is provide a sketch of the different meanings of independence and more importantly a reminder of how useful the term can be. Independence is not just empty rhetoric. It is not just words. It describes an aspiration, albeit a controversial and elusive one, which is necessary in an ongoing debate about the role that lawyers inevitably play in sustaining a democracy.

Of course, these multiple meanings are often in conflict with one another. They are vague and manipulable but the underlying concept is useful in shaping an ongoing conversation about the role of the profession. It is useful, in part, because it helps form a unique professional identity. This communal identity, in turn, provides a mechanism for evolving self-definition. As Émile Durkheim argued, the professions and occupations provide a way for individuals to imagine themselves as part of a larger community in a world that was becoming and continues to become increasingly atomized. ${ }^{219}$ It provides some

216. For a discussion of the effect of globalization on legal practice, see generally Laurel S. Terry, Trends and Challenges in Lawyer Regulation: The Impact of Globalization and Technology, 80 FordHAM L. ReV. 2661 (2012). Laurel Terry, Carol Silver et al., Transnational Legal Practice, 43 INT'L LAWYER 943 (2009).

217. For a discussion of the role of the profession in promoting the rule of law in emerging democracies, see Gillian K. Hadfield, Don't Forget the Lawyers: The Role of Lawyers in Promoting the Rule of Law in Emerging Market Democracies, 56 DePAUL L. REv. 401, 407-08 (2009).

218. For a contemporary argument on this issue, see David Wilkins, Race, Ethics, and the First Amendment: Should a Black Lawyer Represent the Ku Klux Klan, 63 GEO. WASH. L. REV. 1030,1033 (1995) (concluding that a black lawyer should not represent the leader of the Klu Klux Klan, despite his commitments to First Amendment rights).

219. Thomas L. Haskell, Professionalism Versus Capitalism: R.H. Tawney, Émile 
connection between the everyday problems of Americans with its broader pronouncements of value and tradition. ${ }^{220}$ In other words, the very process of trying to figure out what independence means in any given instance proves useful in that it encourages lawyers to imagine what their role ought to be as society changes.

\section{IMPLICATIONS FOR A MODERN CONCEPT OF PROFESSIONAL INDEPENDENCE}

This final section highlights how the history of the profession helps redefine independence in a way that is both suitable to a modern and rapidly changing legal profession and divorces the term from the negative, monopolistic, elitist connotations of the past.

By teasing out a definition of independence, which is more suitable to the legal profession now, this Part also begins to explore what conditions are necessary to ensure independence. ${ }^{21}$ The historical episodes discussed in this Article lend insight to this puzzle by illustrating that professional independence in its shifting and evolving meaning is a product of professional identity formed through communal pursuit and the common task of negotiating private interest and social norms, and that identity in turn is largely independent of the structural relationships that shape a lawyer's work. ${ }^{222}$ Understanding independence in this way has important implications for contemporary debates.

This Part will elaborate how these episodes in the history of the profession cast independence as a product of professional identity and it will begin to explore the implications of this new way of looking at professional values.

\section{A. The Correspondence Between Bowles and Field}

The scuffle over Field's representation of Fisk and Gould points to a potential, if not inevitable, tension between two different understandings

Durkheim, and C.S. Peirce on the Disinterestedness of Professional Communities, in THE AUTHORITY OF EXPERTS: STUDIES IN HISTORY AND THEORY 180 (Thomas L. Haskell ed., 1933); Émile Durkheim, The Division of LABOR IN SOCIETY 49 (George Simpson trans. 1933) (1893).

220. This was essentially that the functional sociologists made by the structural functionalist sociologists. ABEL, supra note 6, at 33-39.

221. Others have begun to answer this question. Most importantly, Robert Gordon has provided a crucial piece of the puzzle. Gordon, supra note 29.

222. Scholars of the profession tend to view independence and other values unique to the profession as a part of the profession's (or judicial system's) legitimacy. See generally WENDEL, supra note 35; LUBAN, supra note 42; WILliam H. SimON, THE PRACTICE OF JUSTICE: A THEORY OF LAWYERS' ETHICS (2000); MARKOVITS, supra note 4. This Article shifts the debate by focusing instead on evolving group identity and its attributes. 
of professional independence. Field insisted that by representing the robber barons he was living up to this ideal. ${ }^{223} \mathrm{He}$ did not embrace or endorse his clients' conduct, ${ }^{224}$ but he leant his considerable expertise to their cause so that the courts could sort out what was right. ${ }^{225}$ According to Field, his role was not to determine right or wrong but rather to present the facts and argue the law as best he could so the judge could ultimately arrive at the just solution. ${ }^{226}$ According to Field, it was Bowles' vision that threatened professional independence by harming his reputation in the press and suggesting that he should not have represented the robber barons. ${ }^{227}$ In Field's opinion, Bowles undermined independence by associating a lawyer with his client's cause. ${ }^{228}$

Bowles disagreed about the meaning of independence. ${ }^{229} \mathrm{He}$ balked at Field's invocation of Erskine, explaining that Erskine remained independent of his client's cause so that he could fight for a public goodin Erskine's case free speech. ${ }^{230}$ Bowles explained that Field had no such cause. ${ }^{231}$ His clients continued to undermine the market and defraud investors. ${ }^{232}$ His clients bribed judges and bought legislative votes and judicial opinions in order to do so. ${ }^{233}$ By representing his client, Field was not standing up for the right to an unpopular opinion but rather assisting ruthless businessmen in committing criminal acts. ${ }^{234}$ Independence, in Bowles' opinion, was a means to an end and a state of professional distance that allowed lawyers to pick their clients and to conduct their cases in the interest of justice and the community as a whole. ${ }^{235}$

Charles Stimson's remarks about prominent lawyers representing accused terrorists and the public outcry that followed illustrates that both the threat to independence as Field understood it and the faith in its essential importance persist. ${ }^{236}$ The fact that Stimson was ultimately forced to resign over the flap indicates that the tide of public opinion has shifted. Unpopular clients deserve representation. When they face the full

223. See supra Part II.A.

224. See supra Part II.A.

225. See supra Part II.A.

226. Field was expressing an early iteration of what William Simon would later call the ethics of neutrality. See William H. Simon, The Ideology of Advocacy, 1978 WISC. L. REV. 29, 32.

227. See supra Part II.A.

228. See supra Part II.A.

229. See supra Part II.A.

230. See supra Part II.A.

231. See supra Part II.A.

232. See supra Part II.A.

233. See supra Part II.A.

234. See supra Part II.A.

235. See supra Part II.A.

236. Lewis, supra note 139. 
force of the government, they may even deserve the very best representation. Field's view, largely denounced by his contemporaries, has come to dominate.

The historical shift in understanding of independence is important itself. ${ }^{237}$ When the greatest perceived threat comes from a private interest, like the robber barons, Bowles' understanding about the need to remain independent from client interests and work toward the good of the public tends to prevail. When the threat arises from government intrusion, then the focus tends to shift toward a need to ensure that lawyers can represent any client and force the government to act lawfully. Either way, independence does manage to define the lawyer's role in preserving liberty.

The conversation between Field and Bowles also helps to highlight the similarity between these two seemingly opposite understandings of professional independence. Just as Erskine was defending free speech rather than his client, Tom Paine's, political beliefs, so too were these prominent lawyers of Guantanamo detainees defending civil liberties against the growing intrusion of the state. Independence was not initially seen as a good in itself. It was valuable insofar as it enabled a professional to use his judgment to pursue the interests of the broader community as well as the client. At times, the two are compatible, and at others they are not. In Bowles' view, by representing the railroad moguls, Field had betrayed the interests of the whole by working to help a corrupt system facilitate their manipulation of the market. ${ }^{238}$ In Field's view, the two were compatible because by representing his client, he was ensuring that each client could secure a good representation. ${ }^{239}$

The message that has been somewhat lost in the passage of time is that independence was never intended to be an end in itself. It is not, at least not as initially conceived, simply good to maintain distance from one's client and his or her goals or deeds. It is good to do so only insofar as the distance allows the lawyer to better evaluate and fight for the good of the community as a whole. In choosing clients and selecting a strategy for the representation, professional independence might require some eye toward the ultimate, substantive good. ${ }^{240}$

237. For a historical account of this shift, see Robert W. Gordon, "The Ideal and the Actual in the Law": Fantasies and Practices of New York City Lawyers, 1870-1910, in THE NEW HIGH PRIESTS: LAWYERS IN POST CIVIL-WAR AMERICA 51 (Gerard W. Gawalt ed., 1984).

238. See supra Part II.A.

239. See supra Part II.A.

240. This is not, of course, a new observation. Critics have engaged in this discussion for quite some time. On one hand, scholars claim that lawyers have an obligation to balance client loyalty with a dedication to the justice and other socially valuable goals. See generally LUBAN, supra note 42; Gordon, supra note 29; Ethical Discretion, supra note 42. On the other hand, others advocate zealous advocacy, claiming that lawyers ought to protect client autonomy and dignity beyond all else. Monroe H. Freedman, Understanding Lawyers' Ethics (1990); Charles 
Part of the disagreement between Field and Bowles about the meaning of independence rests on a distinction between public and private roles. Bowles argued that the lawyer was a public figure while Field insisted that he was a private citizen. ${ }^{241}$ Part of what motivated Field and perhaps led to his different approach to independence, was the complete delegation of moral decision-making to public or government officials. ${ }^{242}$ In Field's view, it was the judge's job, not his own, to decide whether his clients were bad or good, guilty or not. ${ }^{243}$ As contemporary critics have pointed out, this absolute delegation of moral or political decisionmaking is problematic. ${ }^{244}$ If, as most observers would now agree, the law is not a fixed set of principles but rather a product of human choices and context, then the lawyer must have some role in determining its scope and meaning.

Ever since the New Deal, political scientists have insisted that the divide between public and private is not so stark. ${ }^{245}$ Lawyers, citizens, corporations, and other occupations share in the role of governance. Recently, legal scholars have picked up on this point as well. ${ }^{246}$ If this is so, at least a partial return to Bowles' view of the professional would suit the current understanding of how a democratic country is governed. At times and in certain contexts such as criminal defense work, it may be that the best way for an attorney to protect the rule of law is to represent even the most despised person. However, at other times, as in the case of the robber barons, perhaps it would be better to exercise a different sort of independence, focusing on how to use one's talents to promote rather than undermine the law.

The history of independence contributes to the debate over the proper relationship between lawyers and their clients and professional ethics and morality. Most moral philosophers and legal ethicists focus on justice, ${ }^{247}$

Fried, Lawyer as Friend: The Moral Foundations of the Lawyer Client Relation, 85 YALE L.J. 1060 (1976); Stephen L. Pepper, The Lawyer's Amoral Ethical Role: A Defense, A Problem, and Some Possibilities, 1986 AM. B. FOUND. RES. J. 613. Bowles' and Field's disagreement over the meaning of professional independence, however, sheds new light on the issue.

241. For background on the evolution of the notion of public and private, see MORTON J. Horwitz, The Transformation of American Law: THE CRisis of Legal OrTHOdoxy, 18701960 , at 3-33 (1992).

242. See supra Part II.A.

243. See supra Part II.A.

244. LUBAN, supra note 42; SIMON, supra note 222; WENDEL, supra note 35.

245. Rebecca Roiphe, The Most Dangerous Profession, 39 CoNN. L. REV. 603, 605-29 (2006).

246. Orly Lobel, The Renew Deal: The Fall of Regulation and the Rise of Governance in Contemporary Legal Thought, 89 MINN. L. REV. 342 (2004); Bradley C. Karkkainen, "New Governance" in Legal Thought and in the World: Some Splitting as Antidote to Overzealous Lumping, 89 MiNN. L. REV. 471 (2004).

247. LUBAN, supra note 42; SIMON, supra note 222. 
the politics of law-making, ${ }^{248}$ or the legitimacy of the system ${ }^{249}$ to argue that lawyers should be more or less beholden to the will of their clients. Daniel Markovits, for instance, argues that the legitimacy of the adjudicatory system depends on the lawyer's ability to suspend his own personal morality and inclinations to effectuate his client's goals. ${ }^{250}$ David Luban and William Simon, on the other hand, emphasize justice in arguing that the lawyer has an obligation and responsibility to the ultimate outcome of the representation. ${ }^{251} \mathrm{~W}$. Bradley Wendel grounds legal ethics in politics and law making rather than morality. ${ }^{252}$

While not necessarily inconsistent with any of these theories, my focus on independence as an aspect of identity shifts the debate. Markovits's argument fails not necessarily because it abandons justice or rule of law principles but rather because it misconstrues the identity of the lawyer. While Markovits prides himself on accurately describing the practicing bar, he caricatures what it is that lawyers do. ${ }^{253}$ His conception deprives lawyers of their role in negotiating their own personal morality and social or cultural beliefs with that of the client and the dictates of the law. It is this inevitable back and forth, negotiation of opposite principles, and the fluidity or multiplicity of identity that holds the profession together and helps it to serve as a mediator between private interests and the dictates of the law. ${ }^{254}$ The identification with the client combined with a distance grounded in professional identity forces the lawyer to negotiate the client's interest with something that one could characterize as the law or the public interest.

Lurking beneath this debate has always been some question or implication about the effect of increased diversity on the legal profession. In most accounts of the decline of the profession, there is at least some sense that its increasingly differentiated ranks make the cohesion and public stature of the profession difficult if not impossible. ${ }^{255}$ Anthony

248. WENDEL, supra note 35.

249. MARKOVITS, supra note 4.

250. Id. at $1-24$.

251. LUBAN, supra note 42; SIMON, supra note 222.

252. WENDEL, supra note 35 , at 2.

253. MARKOVITS, supra note 4, at 3-6,8.

254. Some scholars have explored the multiplicity of identity in different contexts. Russell Pearce and Eli Wald have developed an understanding of lawyers work from what they term a "relational theory," which posits that clients and lawyers perceive their own self-interest in relation to others. See, e.g., Russell G. Pearce \& Eli Wald, Rethinking Lawyer Regulation: How a Relational Approach Would Improve Lawyer's Rules and Roles, 2012 MicH. ST. L. REV. 513, 529-33. Professor Pearce has also argued that the lawyer's faith does and should shape her approach to lawyering. See Russell G. Pearce, Foreword: The Religious Lawyering Movement: An Emerging Force in Legal Ethics and Professionalism, 66 FORDHAM L. REV. 1075, 1076-77 (1988).

255. MARKOVITS, supra note 4; KRONMAN, supra note 4. 
Kronman, most notably, attributed the decline of the public profession to the newcomers, immigrants, and minorities who now populate its ranks. ${ }^{256}$ Markovits, whose account allows for a meager role for lawyers, more recently cites diversity within the profession as the reason why lawyers can no longer live a meaningful, fulfilling life. ${ }^{257}$

By casting independence as an aspect of identity, my account provides a counter-narrative. Independence, reconceived as an aspect of identity, is an almost inevitable process of negotiation between the client's interests, the lawyer's personal convictions, and the will of the people articulated through the law. Understood in this way, the lawyer never succumbs to any one particular view, because her job requires her to inhabit multiple perspectives at once. This understanding of independence does not remain agnostic as to the diversity of the profession and the population in modern America, but rather celebrates it as a condition in which independence, understood as a product of a complex identity, can thrive. The legal profession must maintain its identity and integrity but in this scheme, it need not isolate itself in order to do so. In fact, its identity is inherent in lawyers' constant exposure to different views and perspectives. Independence requires a lawyer who is constantly shifting perspectives by inhabiting his prior assumptions, his client's views, and that of the law in rapid sequence. Given this understanding, then diversity is a positive good not a cause for concern.

This new understanding of independence is more suitable to a changing modern legal profession. Rather than suppress or lament diversity or yearn for insularity among practitioners, it celebrates the unique ability of lawyers to move in and out of different and often conflicting perspectives. ${ }^{258}$ Rather than experience it as a threat to a meaningful life or a worthy practice, diversity becomes a cornerstone of legal practice and the key to independence. It is not that lawyers, unlike businessmen, are uniquely selfless or talented in assessing the public good, it is that the work lawyers do requires them to inhabit and negotiate multiple beliefs, practices, and commitments that process fosters independence.

256. KRONMAN, supra note 4.

257. To be fair, Markovits does not explicitly decry the diversity in the legal profession but rather laments the loss of "insularity" in the profession. MARKOVITS, supra note 4, at 12 . But, in essence, what he labels the new "cosmopolitan" nature of the profession is code for its diversity, as well as its proximity and overlap with other people and other occupations. It is a way of saying that the bar failed to retain its unique and cohesive identity. Id. at 212-47. In my model, what is unique about the legal profession is precisely its lack of cohesion-its constant negotiation between opposing perspectives and ideas.

258. For a related argument about the value of diverse perspectives, see DeStefano, supra note 10 , at $2795-97$. 


\section{B. A Federally Funded Legal Service Corporation}

The controversy over the Legal Services Corporation (LSC) similarly sheds light on the contemporary debate over independence. ${ }^{259}$ Those who opposed the idea of the LSC were concerned that the structural relationship between the government and the organization would undermine the independence of the staff attorneys. ${ }^{260}$ They were concerned that the legal service attorneys would not be able to stand up to the government, forcing it to behave lawfully and fairly toward the country's poor. ${ }^{261}$ The structural relationship between the government and its employees, the legal services lawyers, would preclude such independence. ${ }^{262}$ In the end, this proved an unnecessary fear. ${ }^{263}$ It was so far from the reality that Vice President Agnew voiced his increasing concern that the lawyers were somehow unaccountable. ${ }^{264}$ They were presenting such a formidable challenge to the administration that Agnew accused the LSC lawyers of being too independent. ${ }^{265}$

This example suggests that independence may not be a product of a structural arrangement but rather an aspect of professional identity. This group identity can, in fact, serve as a bulwark against an attempt to undermine the lawyer's role in defending the law and public interest. The government, after all, was unsuccessful in crusading against the lawyers it funded based on the assertion that they had become too independent. ${ }^{266}$ The strength of the lawyers' views about the meaning and promise of the laws were fierce and not easily undermined by threats or even fairly severe changes to the funding of their services.

This episode in the history of the profession shows that the mounting concern over the danger that multidisciplinary practice and outside funding of law firms pose must be overblown. If the government officials who directly paid the lawyers' salaries in the early 1970s could not control their employees from their spirited attack on government policies then it is certainly logical (if not necessary) to conclude that working with and receiving investments from non-lawyers might similarly prove to have little effect on independent professional judgment.

259. See supra Part II.B.

260. See supra Part II.B.

261. See supra Part II.B.

262. See supra Part II.B.

263. See supra Part II.B.

264. See supra Part II.B.

265. The argument over the LSC echoed concerns about the Court itself representing an unaccountable counter-majoritarian force. ALEXANDER BICKEL, THE LEAST DANGEROUS BRANCH: THE SUPREME COURT AT THE BAR OF POLITICS 16-19 (1986); Barry Friedman, The History of the Countermajoritarian Difficulty, Part I: The Road to Judicial Supremacy, 73 N.Y.U. L. REv.333, 343-56 (1998).

266. See supra Part II.B. 
Once we reconceive of independence as an aspect of group identity, which can serve useful goals, it becomes clear that the profession would be well served with more research on how professional identity is created and fostered. ${ }^{267}$

Echoes of the LSC episode remain. For instance, fairly recently, regulated industries attacked law school clinics, which represented clients in environmental cases. ${ }^{268}$ The clinicians and their students were lending clients the tools to undermine the interests of wealthy industries. Powerful interests do not like an independent bar when it represents those out of power challenging their position of authority. The same interests will invariably try to use political power to hobble their opponents by restricting their access to lawyers. Despite these attempts, the bar persists in its effort to oppose power-both in the form of powerful economic interests and the government. It does so, I argue, because of a continuing (though contested) group identity, which includes a commitment to independence, an independence which requires the negotiation between client interests, the lawyer's own moral and political commitments, along with the dictates of the law.

If we care that lawyers maintain sufficient independence from the government to challenge the legality of its actions and sufficient distance from private factions to confront their concentration of wealth, what should we do? What conditions will best promote an independent legal profession? I have suggested that the ABA is wrong in assuming that lawyers' proximity to other professionals and external sources of funding are the critical factor.

\section{The McCarthy Era}

If, as the previous section demonstrates, structural relationships, like the sources of funding for legal services, do not compromise professional independence, then what does? The revised history of the McCarthy Era loyalty oaths helps to answer that question. ${ }^{269}$ A purge of the ranks of the profession of those who represent people with diverse and unpopular political views is a clear assault on a profession that has defined itself as independent from political control. It denies the profession the ability to negotiate between different perspectives and values, by refusing to allow lawyers to represent those with views different from their own and

267. Psychologists and sociologists have developed multiple theories on individual and group identity formation. Erik Erikson developed a foundational theory. ERIK ERIKSON, IDENTITY AND THE LIFE CYCLE (1980). Others have built on Erikson's theory of identity formation to develop theories of group identity. See, e.g., HAROLD R. ISAACS, IDOLS OF THE TRIBE (1975).

268. David Luban, Taking Out the Adversary: The Assault on Progressive Public Interest Lawyers, 91 CAL. L. REV. 209, 236-40 (2003).

269. See supra Part II.C. 
distinct from those embraced by a majority of the public. Independence, reconceived as the work lawyers do in balancing their own beliefs with those of the client and the dictates of the law, cannot exist under these conditions. The government intentionally conflated the lawyer with the client and forbade the tension with a mainstream ideological consensus.

As many of those who objected at the time noted, the profession is supposed to defend rights and liberties, to stand up for common interests even when those interests are not popular. ${ }^{270}$ Lawyers are supposed to negotiate private interest with public good. The oaths directly compromised that central function of lawyers and stripped the profession of a way to understand its work and its unique relation to the law and democracy.

This Part shows that the profession is far more resilient than we seem to let on. Professional identity, while never monolithic, is one of the axes along which individuals choose to define themselves. Religion, gender, ethnicity, and political beliefs are others. Professional identity is only one piece of a complex puzzle. But the diversity of reactions to the McCarthy Era loyalty oaths show that professional identity has the potential to shape choices and action, even when there is a great deal of pressure. Some lawyers, bar associations, and professional political groups drew on their sense of the role of lawyers as an independent legal profession to resist the intense political pressure to avoid controversial cases and clients. ${ }^{271}$

This Part also sheds light on the perennial debate illustrated by the Bowles and Fields correspondence. The flexibility of independence allows it to adapt to different times and different concerns. When the threat to democratic values comes from powerful private factions then Bowles' conception of independence as the right to choose clients to support the good of the community prevails. ${ }^{272}$ When the danger comes from government repression, as in the McCarthy era, then the bar and the public tend to echo Fields's concern about the right of lawyers to represent even the most despised client to protect liberty from government overreaching. ${ }^{273}$

\section{CONCLUSION}

Reconceiving professional independence as an aspect of group identity rather than an ideology based on the distinction between law and business serves several purposes. First, it helps preserve the positive aspects of professionalism without perpetuating the protectionist and

270. See supra Part II.C.

271. See supra Part II.C.

272. See supra Part II.C.

273. See supra Part II.C. 
elitist uses for which the notion of professional independence has been used in the past. Second, it focuses the ongoing debate about the future of the profession and legal education, allowing room for the profession not only to embrace the changing nature of legal services but also to shape it. Finally, it contributes to an ongoing debate about the role of lawyers in a democratic state.

Many contemporary scholars of the legal profession in America criticize the Bar for resisting proposals to deregulate the profession in ways that might make the delivery of legal services more efficient and help provide a greater number of people with access to the justice system. ${ }^{274}$ It is misguided to use professional independence to support proposals that seem to preserve professional prerogatives at the cost of the public's access to justice. ${ }^{275}$ The ABA has invoked independence to resist proposals that would allow innovations, such as multidisciplinary practice, ${ }^{276}$ alternative litigation financing, ${ }^{277}$ and outside investment in law firms. ${ }^{278}$ If independence, as I have argued, is not created by structural relationships but rather through group identity, then the ABA's fear is not only unwarranted but also counterproductive. Lawyers' identity as a group working to realize clients' interests in the context of group norms will be strengthened, not weakened, by proposals that will increase the efficiency of legal services and ensure that a greater number of individuals have access to the justice system. Identity is not necessarily insular. It can, in fact, be reinforced by interaction with others who have a different background, training, and focus. ${ }^{279}$

As I have argued, professional independence is valuable, but the proximity to non-lawyers is not the real threat to that independence.

274. MORGAN, supra note 3; DeStefano, supra note 10, at 2808-16; W. Bradley Wendel, Alternative Litigation Finance and Anti-Commodification Norms, 63 DePAUL L. REv. 655, 68692 (2014); W. Bradley Wendel, Foreword, The Professional Monopoly and Its Core Values, 82 FORDHAM L. REV. 2563, 2565 (2014) [hereinafter Wendel, Foreword]; Engstrom, supra note 37; Green, supra note 37, at 1155-57.

275. Wendel, Foreword, supra note 274, at 2565.

276. In July 2000 , the $A B A$ voted to disband the commission on the multidisciplinary practice of law and reject any revision to the model rules to allow greater flexibility. Victoria Kremski, Multidisciplinary Practice and the Main Street Lawyer, 79 MiCH. ST. L.J. 796, 796 (2000).

277. Memorandum Soliciting Comment, ABA Comm'n on Ethics 20/20 Working Grp. on Alt. Litig. Fin. (Nov. 23, 2010), http://www.americanbar.org/content/dam/aba/migrated/2011_ build/ethics_2020/altl_lit_financing_issuespaper.authcheckdam.pdf.

278. Thomas R. Andrews, Nonlawyers in the Business of Law: Does the One Who Has the Gold Really Make the Rules?, 40 HASTINGS L.J. 577, 598 (1989).

279. There has been a great deal of scholarship on identity formation. Since the early 1980 s, feminists have elaborated a theory that identity is not a product of autonomy but rather a complex product of group and individual relationships. CAROL GILLIGAN, IN A DIFFERENT VOICE (1982); Kenneth L. Karst, The Women's Constitution, 1984 DuKE L.J. 447; Martha MinNow, MaKING ALL THE DifFERENCE (1990). 
Reframing independence as an aspect of identity helps to refocus concern. We should focus our attention not on inhibiting innovation in the practice of law but rather on promoting a shared identity. One way to do so is by looking at how lawyers are socialized. Legal education is important, not only in preparing lawyers intellectually for the practice of law, but also in lending them a sense of group identity. There are multiple proposals to segment and specialize legal education. ${ }^{280}$ In embracing innovation in education, we need to spend more time thinking about the core that unites all lawyers and how to promote and instill those values in law school and afterwards.

People have never been particularly fond of the legal profession and at least according to some, the reputation of the profession is just getting worse. ${ }^{281}$ As Markovits points out in his book on adversary ethics, lawyers, unlike doctors, are not clearly useful and beneficial. ${ }^{282}$ It is the nature of the adversary system that makes lawyers more of an acquired taste. $^{283}$ If you are fighting on behalf of a client then, as Markovits explains, you are likely to lie and cheat on behalf of your client even when doing so does not advance any general public cause. ${ }^{284}$ While several thoughtful critics have taken issue with this thesis, ${ }^{285}$ it is certainly true that lawyers get a bad reputation for achieving what might be an unjust outcome on behalf of a client who pays their bills.

For years, scholars have debated the role that lawyers ought to play in a democratic society. Reconceiving independence as an aspect of group identity contributes to this debate by shifting the nature of the discussion somewhat. Recently, scholars have attempted to redeem lawyers' roles as adversaries. ${ }^{286}$ By doing so, these scholars celebrate pluralism and criticize any attempt to establish one metric of justice on the grounds that value is by definition plural. ${ }^{287}$ By reconceiving professional

280. TAMANAHA, supra note 11, at 167-86; Elizabeth Chambliss, Two Questions for Law Schools About the Future of the Legal Profession, 36 J.L. Prof. 329, 343-46 (2012).

281. Marc Galanter, Changing Legal Consciousness: The View From the Joke Corpus, 23 CARDOZO L. REV. 2223, 2228-35 (2002).

282. MARKOVITS, supra note 4, at 1 .

283. Id. at $\mathrm{l}-3$.

284. Id.

285. David Luban, A Review of Daniel Markovits, Adversary Advocacy in a Democratic Age, 120 ETHICS 864 (2010).

286. MARKOVITS, supra note 4; Katherine R. Kruse, The Jurisprudential Turn in Legal Ethics, 53 ARIZ. L. REV. 493, 496 (2011); Tim Dare, The Counsel of Rogues? A Defence of the Standard Conception of the Lawyer's Role (2009); Norman W. Spaulding, The Rule of Law in Action: A Defense of Adversary System Values, 93 CoRNELL L. REv. 1377, 1377-78 (2008)

287. Katherine R. Kruse, Lawyers, Justice, and the Challenge of Moral Pluralism, 90 MINN. L. REv. 389, 391 (2005). Kruse concludes that the fundamental moral disagreement leaves us with no way of assessing which view is preferable, therefore we ought to analyze a lawyer's fundamental disagreement with her client by using the conflict of interest principles. Id. at 39394. While I agree that value is plural and disagreements inevitable, my model leaves room for a 
independence as an aspect of group identity, this Article shifts the debate somewhat. There is no doubt that value is plural. This Article's conception of professionalism asserts that while common, shared values, or morality is elusive, it is real. Ironically, it is precisely by exploring and embracing the plurality of value that lawyers can edge toward a common good.

Lawyers, unlike any other profession, are constantly negotiating different and often opposing views. In the real world, they filter their own beliefs and convictions with their client's. Whatever emerges from that negotiation in turn has to be realized in light of the law. This multiplicity of perspectives is unique to the legal profession and lends it a kind of independence, which is one way to approximate morality, justice, or shared norms. 